Original paper

\title{
WinMlgob: A Windows program for magnetite-ilmenite geothermometer and oxygen barometer ${ }^{\dagger}$
}

\author{
Fuat Yavuz
}

Department of Geological Engineering, Istanbul Technical University, 34469 Maslak, Istanbul, Turkey; yavuz@itu.edu.tr

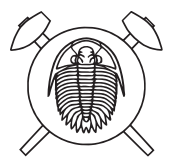

\begin{abstract}
A Microsoft ${ }^{\mathbb{R}}$ Visual Basic software, called WinMIgob, has been developed for wet-chemical and electron-microprobe compositions of coexisting magnetite-ulvöspinel and ilmenite-hematite solid solutions to calculate the temperature ( $T$, ${ }^{\circ} \mathrm{C}$ ) and oxygen fugacity $\left(\mathrm{fO}_{2}\right)$ conditions of magmatic and metamorphic rocks. The program allows the users to enter total of 34 input variables, including Sample $\mathrm{No}, \mathrm{SiO}_{2}, \mathrm{TiO}_{2}, \mathrm{Al}_{2} \mathrm{O}_{3}, \mathrm{~V}_{2} \mathrm{O}_{3}, \mathrm{Cr}_{2} \mathrm{O}_{3}, \mathrm{Nb}_{2} \mathrm{O}_{3}, \mathrm{Fe}_{2} \mathrm{O}_{3}, \mathrm{FeO}, \mathrm{MnO}, \mathrm{NiO}, \mathrm{ZnO}$, $\mathrm{MgO}, \mathrm{CaO}, \mathrm{Na}_{2} \mathrm{O}, \mathrm{K}_{2} \mathrm{O}, \mathrm{BaO}$ (wt. \%) for each magnetite and ilmenite compositional data. WinMIgob enables to enter and load multiple magnetite and ilmenite analyses in the program's data entry section. Alternatively, the composition of magnetite-ilmenite pairs can be typed in a blank Excel file as in the above order and then loaded into the program's data entry screen for data processing. The ferric and ferrous iron contents from microprobe-derived total FeO (wt. \%) of magnetite-ilmenite compositions are estimated by stoichiometric constraints based on three different approaches. Using the calculated multiple magnetite and ilmenite analyses, WinMIgob estimates molecular (\%) and mole fractions of magnetite, uvöspinel, ilmenite and hematite amounts. The program evaluates fourteen magnetite-ilmenite geothermometers, thirteen oxygen barometers and six relative to the nickel-nickel oxide (NNO) buffer values based on the different calibrations with various calculation methods. WinMIgob also allows the users to check if their magnetite-ilmenite pairs taken from rocks are within or departure from the Bacon-Hirschmann $\mathrm{Mg} / \mathrm{Mn}$ exchange equilibrium line $\pm 2 \sigma$ level. This program generates and stores all the calculated results in the Microsoft Excel file (i.e., Output.xlsx), which can be displayed and processed by any other software for further data presentation and graphing purposes. The compiled program code is distributed as a self-extracting setup file, including a help file, test data files and graphic files, which are intended to produce a high-quality printout.
\end{abstract}

Keywords: magnetite, ilmenite, geothermometer, oxygen fugacity, Bacon-Hirschmann, software

Received: 27 August 2020; accepted: 22 March 2021; handling editor: I. Broska

The online version of this article (doi: 10.3190/jgeosci.319) contains supplementary electronic material.

${ }^{*}$ This paper is dedicated to the memory of my father, Servet Yavuz, who passed away in 2020.

\section{Introduction}

The two most common Fe-Ti oxide minerals with magnetite-ulvöspinel $\left(\mathrm{mt}_{\mathrm{ss}}\right)$ and ilmenite-hematite $\left(\mathrm{ilm}_{\mathrm{ss}}\right)$ solid solutions, hereafter referred to as magnetite and ilmenite, respectively, in a variety of rocks and mineral deposits provide the earth scientists valuable information about the temperature of equilibration and corresponding oxygen fugacity conditions (Misra 2012). Consequently, magnetite-ilmenite geothermometry and oxygen barometry have been studied and used widely in igneous and metamorphic petrology with numerous refinements to model the exchange and oxidation reactions since its conception was established in the early 1960s to estimate temperature and oxygen fugacity values, especially for extrusive and hypabyssal igneous rocks that were subjected to the relatively rapid cooling process (Buddington and Lindsley 1964; Carmichael 1967; Anderson 1968; Powell and Powell 1977; Spencer and Lindsley 1981; Lindsley and Spencer 1982; Stormer 1983; Andersen and Lindsley 1988; Ghiorso and Sack 1991; Lattard et al.
2005; Ghiorso and Evans 2008; Sauerzapf et al. 2008). However, at relatively temperature conditions of slow cooling of magmatic rocks or hydrothermal alteration, these minerals tend to display oxide-oxide, intraoxide and oxide-silicate re-equilibration processes after their crystallization history (Venezky and Rutherford 1999). Accordingly, $\mathrm{Fe}-\mathrm{Ti}$ oxide minerals used in magnetiteilmenite geothermometry and oxygen barometry studies rarely preserve their magmatic compositions in slowly cooled plutonic or hydrothermal rocks. Therefore, their application to plutonic igneous rocks and mineral deposits should be considered with caution (Misra 2012; Wang et al. 2014). On the other hand, in many natural magmas, magnetite and ilmenite may not have coprecipitated. Thus, an absence of ilmenite in these rocks prevents the application of magnetite-ilmenite oxygen barometry technique but allows to estimate it based on Fe and Ti's partitioning between magnetite and silicate melt (Arató and Audétat 2017).

The magnetite-ilmenite geothermometer and oxygen barometer model, on a graphical solution, by Buddington 
and Lindsley (1964), was one of the first calibrated study based on temperature and redox-sensitive equilibria between magnetite-ulvöspinel and ilmenite-hematite solid solutions in the $\mathrm{FeO}-\mathrm{Fe}_{2} \mathrm{O}_{3}-\mathrm{TiO}_{2}$ system. Ghiorso and Carmichael (1981) developed a Fortran IV program for the calculation of temperature and oxygen fugacity using the mole fractions of ulvöspinel $\left(\mathrm{Fe}_{2} \mathrm{TiO}_{4}\right)$ and hematite $\left(\mathrm{Fe}_{2} \mathrm{O}_{3}\right)$ from compositions of coexisting $\mathrm{Fe}-\mathrm{Ti}$ oxide pairs in rocks. Their approach depends essentially on the graphical interpolation from published smoothed calibration curves by Buddington and Lindsley (1964). Rao et al. (1991) presented an interactive Basic program of $\mathrm{Fe}-\mathrm{Ti}$ oxide thermometry, called ITHERM, to calculate temperatures of equilibrium using the methods of Powell and Powell (1977), Spencer and Lindsley (1981), and Andersen and Lindsley (1985). Lepage (2003) developed an Excel spreadsheet (ILMAT) solely on the magnetiteilmenite geothermometry, but also calculating oxygen fugacity based on the empirical approach proposed by several authors (e.g., Spencer and Lindsley 1981; Andersen and Lindsley 1985). The logic of ILMAT was taken from ITHERM (Rao et al. 1991) with revision and correction on magnetite-ilmenite geothermometry estimations. Hora et al. (2013) presented three Excel spreadsheets for two mineral pairs, including magnetite-ilmenite (Ghiorso and Evans 2008), amphibole-plagioclase (Holland and Blundy 1994) and two feldspar (Putirka 2008) geothermometers with a technique facilitating geothermobarometry estimations on a large number of analyses. When compared to the other two amphibole-plagioclase and two feldspar geothermometers, magnetite-ilmenite geothermometer approach uses an AppleScript to transfer input magnetite and ilmenite analyses from Mac OSX Excel to the standalone application and to receive the calculated results back to the Excel platform (Hora et al. 2013).

In this paper, a new computer program, called WinMIgob, is developed using the Microsoft ${ }^{\circledR}$ Visual Basic programming language to calculate multiple magnetite and ilmenite mineral oxides, up to 350 analyses in each program execution, obtained by both wet-chemical and electron-microprobe techniques. The logic of WinMIgob is based on ILMAT, an Excel spreadsheet developed by Lepage (2003), with additional recent magnetite-ilmenite geothermometers and oxygen barometers (e.g., Sauerzapf et al. 2008). The program recalculates magnetite mineral analyses to four oxygens and three total cations and ilmenite analyses to three oxygens and two total cations. WinMIgob is capable of estimating the $\mathrm{Fe}^{3+}$ and $\mathrm{Fe}^{2+}$ contents from electron microprobe-derived total $\mathrm{FeO}$ (wt. \%) analysis based on stoichiometric considerations using different procedures outlined by Carmichael (1967), Stormer (1983) and Droop (1987). Using the recalculated magnetite and ilmenite compositions, the program provides users various geothermometer $\left(T,{ }^{\circ} \mathrm{C}\right)$, oxygen fugacity $\left(\log f \mathrm{O}_{2}\right)$ and relative to the nickel-nickel oxide (NNO) buffer $(\triangle \mathrm{NNO})$ estimations (e.g., Powell and Powell 1977; Spencer and Lindsley 1981; Andersen and Lindsley 1985; Sauerzapf et al. 2008). WinMIgob also calculates magnetite-ilmenite geothermometer and $\triangle \mathrm{NNO}$ developed by Ghiorso and Evans (2008) based on the selected magnetite-ilmenite analyses from literature through linear regression equations between the Andersen and Linsdley (1985) and Sauerzapf et al. (2008) calibrations. WinMIgob provides the user to display magnetite-ilmenite compositions in various binary (e.g., $T\left({ }^{\circ} \mathrm{C}\right)-\log f \mathrm{O}_{2}$ ) and ternary (e.g., Ti- $\mathrm{R}^{2+}-\mathrm{R}^{3+}$ ) diagrams by using the Golden Software's Grapher program. Compared to the previously published computer programs and Excel spreadsheets on $\mathrm{Fe}-\mathrm{Ti}$ oxides, the current version of program presents of the quick evaluation and comparison of multiple magnetite-ilmenite analyses for numerous geothermometry and oxygen fugacity calculations.

\section{Program description}

In comparison of executable computer programs and Excel spreadsheets solely based on the calculation and classification of rock-forming silicate group minerals, a limited number of studies appeared in literature for geothermobarometry estimations (e.g., Yavuz 1998; Putirka 2008; Hora et al. 2013; Yavuz 2013; Lanari et al. 2014; Yavuz and Döner 2017; Li et al. 2019; Yavuz and Yildirim 2020).

WinMIgob is a compiled program presented for running in the Microsoft ${ }^{\circledR}$ Windows platform to estimate the different $\mathrm{Fe}-\mathrm{Ti}$ oxide geothermometer and oxygen fugacity calibrations. The program comes up with a selfextracting setup file $(\approx 20 \mathrm{Mb})$, which is created by the Inno Setup Compiler (https://jrsoftware.org/isinfo.php). It runs as a single executable file, WinMIgob.exe (3.17 $\mathrm{Mb}$ ), on the condition that the Microsoft ${ }^{\circledR}$ Visual Studio package is installed into the same personal computer. On the other hand, with the help of necessary ". $\mathrm{cx}$ " and ". dl l" support files came up with a setup file, the users of this program can execute WinMIgob without requiring the Microsoft ${ }^{\circledR}$ Visual Studio package. Following the successful installation of the program, the start-up screen with various pull-down menus and shortcuts appears. A list of the calculation steps in the program's Calculation Screen and in an Excel output file is given in Tab. 1. The current version of the program presents ten binary and ternary magnetite-ilmenite-related plots. These plots are displayed by selecting a desired diagram type from the pull-down menu of Graph in the Calculation Screen window of WinMIgob. 
Tab. 1 Description of column numbers in the Calculation Screen window of WinMIgob program and an output Excel file

\begin{tabular}{|c|c|c|}
\hline Row & Explanation & $\begin{array}{l}\text { Column } \\
\text { numbers }\end{array}$ \\
\hline 1 & Major oxide magnetite mineral analyses (wt. \%) & $1-17$ \\
\hline 2 & Stoichiometric $\mathrm{Fe}_{2} \mathrm{O}_{3}$ and $\mathrm{FeO}$ (wt. \%) contents from microprobe magnetite analyses & $18-19$ \\
\hline 3 & Recalculated cations of magnetite mineral analyses (apfu) & $20-36$ \\
\hline 4 & Blank & 37 \\
\hline 5 & Major oxide ilmenite mineral analyses (wt. \%) & $38-55$ \\
\hline 6 & Stoichiometric $\mathrm{Fe}_{2} \mathrm{O}_{3}$ and $\mathrm{FeO}$ (wt. \%) contents from microprobe ilmenite analyses & $56-57$ \\
\hline 7 & Recalculated cations of ilmenite mineral analyses $(a p f u)$ & $58-74$ \\
\hline 8 & Blank & 75 \\
\hline 9 & Sum of atomic mole proportion of magnetite and ilmenite analyses & $76-77$ \\
\hline 10 & Molecular ulvöspinel and magnetite amounts (\%) by Carmichael (1967) & $78-79$ \\
\hline 11 & Molecular ilmenite and hematite amounts (\%) by Carmichael (1967) & $80-81$ \\
\hline 12 & Molecular ulvöspinel and ilmenite amounts (\%) by Anderson (1968) & $82-83$ \\
\hline 13 & Molecular ulvöspinel and ilmenite amounts (\%) by Lindsley and Spencer (1982) & $84-85$ \\
\hline 14 & Molecular ulvöspinel and ilmenite amounts (\%) by Stormer (1983) & $86-87$ \\
\hline 15 & Mole fraction of ulvöspinel and magnetite amounts by Spencer and Lindsley (1981) & $88-89$ \\
\hline 16 & Mole fraction of ilmenite and hematite amounts by Spencer and Lindsley (1981) & $90-91$ \\
\hline 17 & Mole fraction of ulvöspinel and magnetite amounts by Sauerzapf et al. (2008) & $92-93$ \\
\hline 18 & Mole fraction of ilmenite and hematite amounts by Sauerzapf et al. (2008) & $94-95$ \\
\hline 19 & Blank & 96 \\
\hline 20 & Magnetite-ilmenite geothermometer $\left({ }^{\circ} \mathrm{C}\right)$ by Powell and Powell (1977) using the Carmichael (1967) calculation method & 97 \\
\hline 21 & Magnetite-ilmenite geothermometer $\left({ }^{\circ} \mathrm{C}\right)$ by Powell and Powell (1977) using the Anderson (1968) calculation method & 98 \\
\hline 22 & $\begin{array}{l}\text { Magnetite-ilmenite geothermometer }\left({ }^{\circ} \mathrm{C}\right) \text { by Powell and Powell (1977) using the Lindsley and Spencer (1982) } \\
\text { calculation method }\end{array}$ & 99 \\
\hline 23 & Magnetite-ilmenite geothermometer $\left({ }^{\circ} \mathrm{C}\right)$ by Powell and Powell $(1977)$ using the Stormer $(1983)$ calculation method & 100 \\
\hline 24 & Magnetite-ilmenite geothermometer $\left({ }^{\circ} \mathrm{C}\right)$ by Spencer and Lindsley (1981) using the Carmichael (1967) calculation method & 101 \\
\hline 25 & Magnetite-ilmenite geothermometer $\left({ }^{\circ} \mathrm{C}\right)$ by Spencer and Lindsley (1981) using the Anderson (1968) calculation method & 102 \\
\hline 26 & $\begin{array}{l}\text { Magnetite-ilmenite geothermometer }\left({ }^{\circ} \mathrm{C}\right) \text { by Spencer and Lindsley (1981) using the Lindsley and Spencer (1982) } \\
\text { calculation method }\end{array}$ & 103 \\
\hline 27 & Magnetite-ilmenite geothermometer $\left({ }^{\circ} \mathrm{C}\right)$ by Spencer and Lindsley $(1981)$ using the Stormer (1983) calculation method & 104 \\
\hline 28 & Magnetite-ilmenite geothermometer $\left({ }^{\circ} \mathrm{C}\right)$ by Andersen and Lindsley $(1985)$ using the Carmichael $(1967)$ calculation method & 105 \\
\hline 29 & Magnetite-ilmenite geothermometer $\left({ }^{\circ} \mathrm{C}\right)$ by Andersen and Lindsley (1985) using the Anderson (1968) calculation method & 106 \\
\hline 30 & $\begin{array}{l}\text { Magnetite-ilmenite geothermometer }\left({ }^{\circ} \mathrm{C}\right) \text { by Andersen and Lindsley (1985) using the Lindsley and Spencer (1982) } \\
\text { calculation method }\end{array}$ & 107 \\
\hline 31 & Magnetite-ilmenite geothermometer $\left({ }^{\circ} \mathrm{C}\right)$ by Andersen and Lindsley (1985) using the Stormer (1983) calculation method & 108 \\
\hline 32 & Magnetite-ilmenite geothermometer $\left({ }^{\circ} \mathrm{C}\right)$ by Sauerzapf et al. (2008) & 109 \\
\hline 33 & $\begin{array}{l}\text { Magnetite-ilmenite geothermometer }\left({ }^{\circ} \mathrm{C}\right) \text { by Ghiorso and Evans (2008) based on the linear regression equation } \\
{\left[T_{\mathrm{GE} 08}\left({ }^{\circ} \mathrm{C}\right)=1.09826 \times T_{\mathrm{S} 08}-67.18938\right]}\end{array}$ & 110 \\
\hline 34 & Blank & 111 \\
\hline 35 & Log oxygen fugacity $\left(f \mathrm{O}_{2}\right)$ by Powell and Powell (1977) using the Carmichael (1967) calculation method & 112 \\
\hline 36 & Log oxygen fugacity $\left(f \mathrm{O}_{2}\right)$ by Powell and Powell (1977) using the Anderson (1968) calculation method & 113 \\
\hline 37 & Log oxygen fugacity $\left(f \mathrm{O}_{2}\right)$ by Powell and Powell (1977) using the Lindsley and Spencer (1982) calculation method & 114 \\
\hline 38 & Log oxygen fugacity $\left(f \mathrm{O}_{2}\right)$ by Powell and Powell (1977) using the Stormer (1983) calculation method & 115 \\
\hline 39 & Log oxygen fugacity $\left(f_{2}\right)$ by Spencer and Lindsley (1981) using the Carmichael (1967) calculation method & 116 \\
\hline 40 & Log oxygen fugacity $\left(f \mathrm{O}_{2}\right)$ by Spencer and Lindsley (1981) using the Anderson (1968) calculation method & 117 \\
\hline 41 & Log oxygen fugacity $\left(f \mathrm{O}_{2}\right)$ by Spencer and Lindsley (1981) using the Lindsley and Spencer (1982) calculation method & 118 \\
\hline 42 & Log oxygen fugacity $\left(f \mathrm{O}_{2}\right)$ by Spencer and Lindsley (1981) using the Stormer (1983) calculation method & 119 \\
\hline 43 & Log oxygen fugacity $\left(f \mathrm{O}_{2}\right)$ by Andersen and Lindsley (1985) using the Carmichael (1967) calculation method & 120 \\
\hline 44 & Log oxygen fugacity $\left(f \mathrm{O}_{2}\right)$ by Andersen and Lindsley (1985) using the Anderson (1968) calculation method & 121 \\
\hline 45 & Log oxygen fugacity $\left(f \mathrm{O}_{2}\right)$ by Andersen and Lindsley (1985) using the Lindsley and Spencer (1982) calculation method & 122 \\
\hline 46 & Log oxygen fugacity $\left(f \mathrm{O}_{2}\right)$ by Andersen and Lindsley (1985) using the Stormer (1968) calculation method & 123 \\
\hline 47 & Log oxygen fugacity $\left(f \mathrm{O}_{2}\right)$ by Sauerzapf et al. (2008) & 124 \\
\hline 48 & Blank & 125 \\
\hline 49 & Log oxygen fugacity $\left(f \mathrm{O}_{2}\right.$, relative to buffer) by Andersen and Lindsley (1985) using the Carmichael (1967) calculation method & 126 \\
\hline 50 & Log oxygen fugacity $\left(f \mathrm{O}_{2}\right.$, relative to buffer) by Andersen and Lindsley (1985) using the Anderson (1968) calculation method & 127 \\
\hline 51 & Log oxygen fugacity $\left(f \mathrm{O}_{2}\right.$, relative to buffer) by Andersen and Lindsley (1985) using the Stormer (1983) calculation method & 128 \\
\hline 52 & Log oxygen fugacity $\left(f \mathrm{O}_{2}\right.$, relative to buffer) by Andersen and Lindsley (1985) using the Stormer (1983) calculation method & 129 \\
\hline
\end{tabular}


Tab. 1 Continued

53 Log oxygen fugacity ( $f \mathrm{O}_{2}$, relative to buffer) by Sauerzapf et al. (2008)

54 Log oxygen fugacity $\left(f \mathrm{O}_{2}\right.$, relative to buffer) by Ghiorso and Evans (2008)

5 Blank

apfu - atoms per formula unit; $T_{\mathrm{GE} 08}-$ (row 33) from Ghiorso and Evans (2008) calculated by online link [http://melts.ofm-research.org/CORBA_CTserver/OxideGeothrm/OxideGeothrm.php]; $T_{\text {s08 }}$ - (row 33) from Excel spreadsheet estimation developed by Sauerzapf et al. (2008)

\subsection{Data entry}

This program's users can type both magnetite and ilmenite analyses by clicking the New icon on the toolbar, by selecting New File from the pull-down menu of File option or pressing the Ctrl $+N$ keys. The standard 17 variables are defined by WinMIgob for calculation of magnetite-ilmenite pairs in the following order:

Sample No[M], $\mathrm{SiO}_{2}[\mathrm{M}], \mathrm{TiO}_{2}[\mathrm{M}], \mathrm{Al}_{2} \mathrm{O}_{3}[\mathrm{M}], \mathrm{V}_{2} \mathrm{O}_{3}[\mathrm{M}]$, $\mathrm{Cr}_{2} \mathrm{O}_{3}[\mathrm{M}], \mathrm{Nb}_{2} \mathrm{O}_{3}[\mathrm{M}], \mathrm{Fe}_{2} \mathrm{O}_{3}[\mathrm{M}], \mathrm{FeO}[\mathrm{M}], \mathrm{MnO}[\mathrm{M}]$, $\mathrm{NiO}[\mathrm{M}], \mathrm{ZnO}[\mathrm{M}], \mathrm{MgO}[\mathrm{M}], \mathrm{CaO}[\mathrm{M}], \mathrm{Na}_{2} \mathrm{O}[\mathrm{M}]$, $\mathrm{K}_{2} \mathrm{O}[\mathrm{M}], \mathrm{BaO}[\mathrm{M}]$ and

Sample $\mathrm{No}[\mathrm{I}], \mathrm{SiO}_{2}[\mathrm{I}], \mathrm{TiO}_{2}[\mathrm{I}], \mathrm{Al}_{2} \mathrm{O}_{3}[\mathrm{I}], \mathrm{V}_{2} \mathrm{O}_{3}[\mathrm{I}]$, $\mathrm{Cr}_{2} \mathrm{O}_{3}[\mathrm{I}], \mathrm{Nb}_{2} \mathrm{O}_{3}[\mathrm{I}], \mathrm{Fe}_{2} \mathrm{O}_{3}[\mathrm{I}], \mathrm{FeO}[\mathrm{I}], \mathrm{MnO}[\mathrm{I}], \mathrm{NiO}[\mathrm{I}]$, $\mathrm{ZnO}[\mathrm{I}], \mathrm{MgO}[\mathrm{I}], \mathrm{CaO}[\mathrm{I}], \mathrm{Na}_{2} \mathrm{O}[\mathrm{I}], \mathrm{K}_{2} \mathrm{O}[\mathrm{I}], \mathrm{BaO}[\mathrm{I}]$,

where $\mathrm{M}$ and $\mathrm{I}$ show the abbreviations of magnetite and ilmenite, respectively. In the data entry section, WinMIgob thus permits the user to enter a total of 34 variables. Magnetite and ilmenite compositions typed in Excel files with the extension of ". xls" and ".xISx" in the above order can be loaded into the program's data entry section (i.e., Data Entry Screen) by clicking the Open Excel File option from the pulldown menu of File. However, using the copy-paste options, these data in the above order from a Microsoft ${ }^{\circledR}$ Excel spreadsheet can be included in the data entry section of WinMIgob more quickly. By selecting the Edit Excel File option from the pull-down menu of File, magnetite and ilmenite compositions can be typed in a blank Excel file (i.e., MyMI) in the (C: Program Files $\backslash$ WinMIgob) folder, stored in a different file name with the extension of ".xls" or ".xlsx", and then loaded into the WinMIgob's data entry section by clicking the Open Excel File option from the pull-down menu of File for further data evaluations. Once the analyses in an Excel file are displayed on the screen by using the Open Excel File option, they can be stored with the extension of ". mi" by clicking the Save As option from the pull-down menu of File. Additional information about data entry or similar topics can be accessed by pressing the F1 function key to display the program's help file on the screen. For example, selecting the File menu section from the index of WinMIgob.chm file, it displays the necessary information concerning the magnetite-ilmenite file operations on the screen.

\subsection{Normalization, ferric iron estimation, geothermometer, oxygen barometer and Bacon-Hirschmann equilibrium test}

Once the program is executed, WinMIgob calculates magnetite analyses to four oxygens and three total cations and ilmenite to three oxygens and two total cations. Magnetite-ilmenite analyses with measured $\mathrm{Fe}_{2} \mathrm{O}_{3}$ (wt. \%) and $\mathrm{FeO}$ (wt. \%) contents (e.g., wet-chemical) are calculated by program as $\mathrm{Fe}^{3+}(a p f u)$ and $\mathrm{Fe}^{2+}(a p f u)$ separately. However, if these analyses are given as $\mathrm{Fe}_{2} \mathrm{O}_{3}$ (wt. \%) $=0$ and $\mathrm{FeO}($ wt. $\%)>0$, then the program considers $\mathrm{FeO}$ (wt. \%) content as $\mathrm{FeO}_{\text {tot }}$ (wt. \%) and estimates the ferric and ferrous iron contents stoichiometrically based on the procedure proposed by Stormer (1983) (Fig. 1a). The ferric iron estimation $\left(\mathrm{Fe}^{3+}, a p f u\right)$ from a total iron content $\left(\mathrm{FeO}_{\text {tot }}, \mathrm{wt} . \%\right)$ of electron-microprobe magnetiteilmenite analysis is also carried out using two other different empirical equations (e.g., Carmichael 1967; Droop 1987) by selecting one of these from the pull-down menu of Ferric iron estimation option in the Data Entry Screen of WinMIgob.

In the estimation of $\log f \mathrm{O}_{2}$, the program assumes input pressure as 2000 bars. However, WinMIgob provides the user to select 1, 1000, 3000 and 5000 bars options from the pull-down menu of Buffer in the Data Entry Screen (Fig. 1b). The program displays $T\left({ }^{\circ} \mathrm{C}\right)-\log f \mathrm{O}_{2}$ graph based on the Andersen and Lindley (1985) calibration using the calculation model by Stormer (1983) as default (Fig. 1c). By selecting other calibrations (e.g., Powell and Powell 1977; Spencer and Lindsley 1981) using different calculation methods (e.g., Carmichael 1967; Anderson 1968; Lindsley and Spencer 1982) from the pull-down menu of Method, WinMIgob displays the corresponding graph on screen with the help of Golden Software's Grapher program. The program provides various geothermometers based on different calibrations (e.g., Powell and Powell 1977; Spencer and Lindsley 1981; Andersen and Lindsley 1985; Sauerzapf et al. 2008). On the other hand, by selecting the second option from the pull-down menu of Geothermometer (see Fig. 1d) in the Data Entry Screen window, WinMIgob also presents the user to estimate Ghiorso and Evans (2008) geothermometer with a high correlation coefficient $(r=0.98)$ based on the linear regression equation $\left[T_{\mathrm{GE} 08}\right.$ $\left.\left({ }^{\circ} \mathrm{C}\right)=1.53448 \times T_{\mathrm{Al} 85}-458.13356\right]$ using the model by 


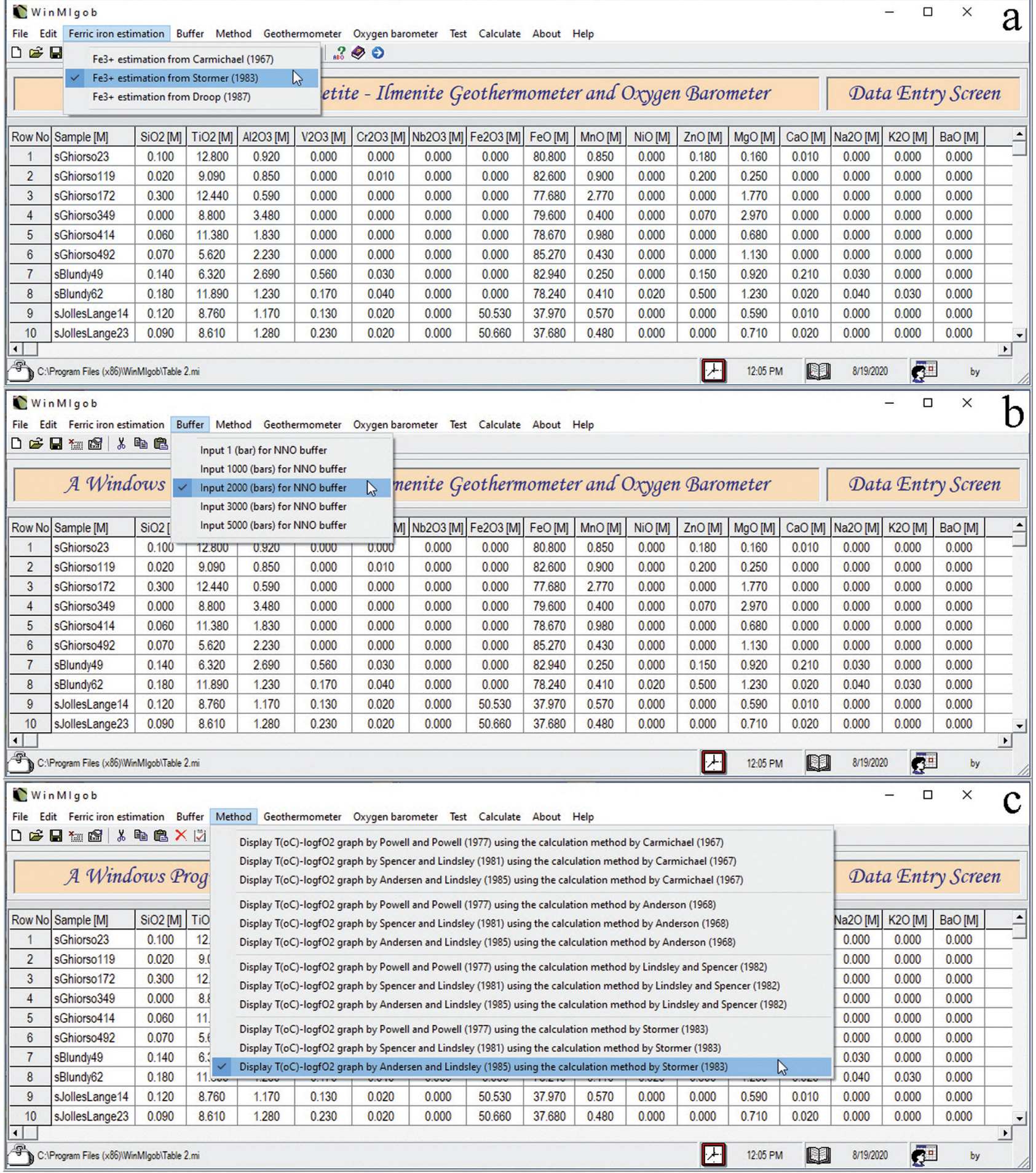

Fig. 1 Screenshots showing the WinMIgob's pull-down menu options for magnetite-ilmenite geothermometer and oxygen barometer estimations. $\mathbf{a}$ - Selecting stoichiometric ferric and ferrous iron calculation procedure. $\mathbf{b}$ - Selecting input pressure (bars) value for relative oxygen fugacity (the nickel-nickel oxide buffer, $\triangle \mathrm{NNO}$ ) estimation. $\mathbf{c}$ - Selecting calibration model to display $T\left({ }^{\circ} \mathrm{C}\right)-\log f \mathrm{O}_{2}$ graph.

Andersen and Lindsley (1985) for 450 magnetite-ilmenite pairs from the literature following the Bacon and Hirschmann's (1988) Mg/Mn exchange test. Similarly, by selecting the second option from the pull-down menu of Oxygen barometer in the Start-up Screen window
(Fig. 1e), WinMIgob calculates the $\triangle \mathrm{NNO}$ values with a high correlation $(r=0.95)$ through a linear regression equation $\left[\Delta \mathrm{NNO}_{\mathrm{GE} 08}=0.99157 \times \Delta \mathrm{NNO}_{\mathrm{AL} 85}-0.04250\right]$ using the Andersen and Lindsley's (1985) and Ghiorso and Evans's (2008) calibrations. 
CWinMIgo

File Edit Ferriciron estimation Buffer Method Geothermometer Oxygen barometer Test Calculate About Help

$\square \times \mathbf{Q}$

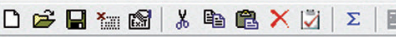

A Windows Program fc

Sauerzapf et al. (2008) thermometer through least-squares using model by Andersen and Lindsley (1985)

Ghiorso and Evans (2008) thermometer through least-squares using model by Andersen and Lindsley (1985)

Data Entry Screen

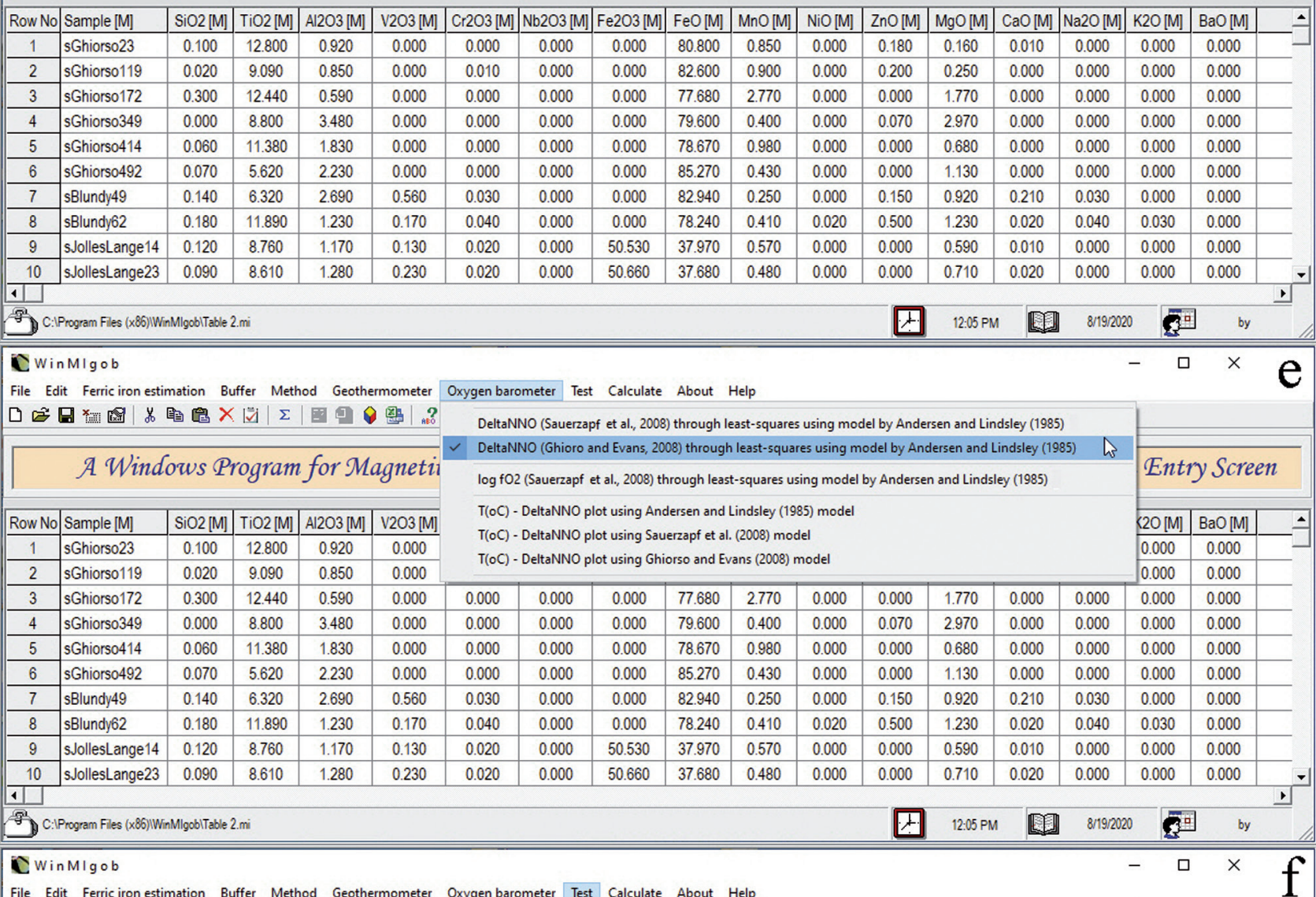

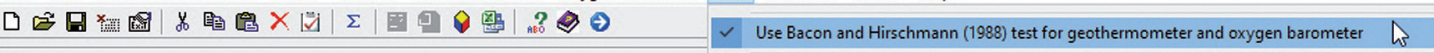

\section{A Windows Program for Magnetite - Ilmenite Geothermometer and Oxygen Barometer}

Data Entry Screen

\begin{tabular}{|c|c|c|c|c|c|c|c|c|c|c|c|c|c|c|c|c|c|c|}
\hline Row No & Sample [M] & $\mathrm{SiO} 2[\mathrm{M}]$ & $\mathrm{TiO} 2[\mathrm{M}]$ & $\mathrm{Al} 2 \mathrm{O} 3[\mathrm{M}]$ & $\mathrm{V} 2 \mathrm{O} 3[\mathrm{M}]$ & $\mathrm{Cr} 2 \mathrm{O} 3[\mathrm{M}]$ & $\mathrm{Nb} 2 \mathrm{O} 3$ [M] & $\mathrm{Fe} 2 \mathrm{O} 3[\mathrm{M}]$ & $\mathrm{FeO}[\mathrm{M}]$ & $\mathrm{MnO}[\mathrm{M}]$ & $\mathrm{NiO}[\mathrm{M}]$ & $\mathrm{ZnO}[\mathrm{M}]$ & $\mathrm{MgO}[\mathrm{M}]$ & $\mathrm{CaO}[\mathrm{M}]$ & $\mathrm{Na} 2 \mathrm{O}[\mathrm{M}]$ & $\mathrm{K} 2 \mathrm{O}[\mathrm{M}]$ & $\mathrm{BaO}[\mathrm{M}]$ & 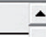 \\
\hline 1 & sGhiorso23 & 0.100 & 12.800 & 0.920 & 0.000 & 0.000 & 0.000 & 0.000 & 80.800 & 0.850 & 0.000 & 0.180 & 0.160 & 0.010 & 0.000 & 0.000 & 0.000 & \\
\hline 2 & sGhiorso119 & 0.020 & 9.090 & 0.850 & 0.000 & 0.010 & 0.000 & 0.000 & 82.600 & 0.900 & 0.000 & 0.200 & 0.250 & 0.000 & 0.000 & 0.000 & 0.000 & \\
\hline 3 & sGhiorso172 & 0.300 & 12.440 & 0.590 & 0.000 & 0.000 & 0.000 & 0.000 & 77.680 & 2.770 & 0.000 & 0.000 & 1.770 & 0.000 & 0.000 & 0.000 & 0.000 & \\
\hline 5 & sGhiors0414 & 0.060 & 11.380 & 1.830 & 0.000 & 0.000 & 0.000 & 0.000 & 78.670 & 0.980 & 0.000 & 0.000 & 0.680 & 0.000 & 0.000 & 0.000 & 0.000 & \\
\hline 6 & sGhiors0492 & 0.070 & 5.620 & 2.230 & 0.000 & 0.000 & 0.000 & 0.000 & 85.270 & 0.430 & 0.000 & 0.000 & 1.130 & 0.000 & 0.000 & 0.000 & 0.000 & \\
\hline 7 & sBlundy 49 & 0.140 & 6.320 & 2.690 & 0.560 & 0.030 & 0.000 & 0.000 & 82.940 & 0.250 & 0.000 & 0.150 & 0.920 & 0.210 & 0.030 & 0.000 & 0.000 & \\
\hline 8 & sBlundy 62 & 0.180 & 11.890 & 1.230 & 0.170 & 0.040 & 0.000 & 0.000 & 78.240 & 0.410 & 0.020 & 0.500 & 1.230 & 0.020 & 0.040 & 0.030 & 0.000 & \\
\hline 9 & sJollesLange 14 & 0.120 & 8.760 & 1.170 & 0.130 & 0.020 & 0.000 & 50.530 & 37.970 & 0.570 & 0.000 & 0.000 & 0.590 & 0.010 & 0.000 & 0.000 & 0.000 & \\
\hline 10 & sJollesLange 23 & 0.090 & 8.610 & 1.280 & 0.230 & 0.020 & 0.000 & 50.660 & 37.680 & 0.480 & 0.000 & 0.000 & 0.710 & 0.020 & 0.000 & 0.000 & 0.000 & - \\
\hline \begin{tabular}{|l|l|}
1 & \\
\end{tabular} & & & & & & & 1 \\
\hline \multicolumn{18}{|l|}{ ginc } & \\
\hline
\end{tabular}

Fig. 1 Screenshots showing the WinMIgob's pull-down menu options for magnetite-ilmenite geothermometer and oxygen barometer estimations. d-Selecting magnetite-ilmenite geothermometer through least-squares using the model by Andersen and Lindsley (1985) (rows 15-16 in Tab. 3). e - Selecting magnetite-ilmenite relative oxygen barometer (the nickel-nickel oxide buffer, $\Delta$ NNO) (rows 40-41 in Tab. 3) and log oxygen fugacity (row 32 in Tab. 3) options using the model by Andersen and Lindsley (1985). f - Selecting the Bacon and Hirscmann (1988) equilibrium test for magnetite-ilmenite pairs. By clicking this option, magnetite-ilmenite geothermometer and oxygen barometer estimations are ignored, if any of sample does not pass the test.

WinMIgob allows the user to test the coexistence of analyzed magnetite-ilmenite pairs by clicking the Use
Bacon and Hirschmann (1988) test for geothermometer and oxygen barometer option from the pull-down menu 
of Test in the Data Entry Screen window (Fig. 1f). If coexisting oxides successfully pass the test, the program warns the user in column number 133 of the Calculation Screen window with "Passed", otherwise "Failed" statements. If the Bacon-Hirschmann test option is clicked (see Fig. 1f), but "Failed" statement is encountered for any sample, then WinMIgob does not list the calculated $\mathrm{Fe}-\mathrm{Ti}$ oxide geothermometers and oxygen barometers in the Calculation Screen. Bacon and Hirschmann (1988) proposed that partitioning of $\mathrm{Mg}$ and $\mathrm{Mn}$ between titanomagnetite and ferrian ilmenite of volcanic rocks can be used as a test for equilibrium between coexisting phases. According to Bacon and Hirschmann (1988), the Mg/Mn magnetite-ilmenite partitioning test appears to be valid for fresh volcanic rocks but inapplicable to pairs in metamorphic, plutonic, and altered volcanic rocks due to these minerals typically have oxidized or exsolved at subsolidus temperatures. The logic of test, in a plot of ilmenite $\log (\mathrm{Mg} / \mathrm{Mn})$ versus magnetite $\log (\mathrm{Mg} / \mathrm{Mn})$ plot (Fig. 2), is based on to define the quality of analytical data and whether Fe-Ti oxide pairs have had their compositions altered by post-eruptive processes. Departures from the Bacon-Hirschmann line $\left[\log (\mathrm{Mg} / \mathrm{Mn})_{\mathrm{Mag}}=0.9317 \times \log \right.$ $\left.(\mathrm{Mg} / \mathrm{Mn})_{\operatorname{IIm}}-0.0909\right]$ within two standard deviations of the equilibrium line $( \pm 2 \sigma)$ provide an empirical evaluation of the extent to which $\mathrm{Fe}-\mathrm{Ti}$ oxide pairs are out of $\mathrm{Mg} / \mathrm{Mn}$ exchange equilibrium. Thus, we can assume that if the $\mathrm{Fe}-\mathrm{Ti}$ oxides are in $\mathrm{Mg} / \mathrm{Mn}$ exchange equilibrium, then it is more likely that their bulk compositions reflect equilibration under the pre-eruptive temperature and oxygen fugacity conditions (Ghiorso and Evans 2008).

\section{Worked examples}

Using the selected dataset from literature (see Electronic Supplementary Material, ESM 1), the following examples show

Fig. 2 An application of $\mathrm{Mg} / \mathrm{Mn}$ exchange test (Bacon and Hirschmann 1988) for magnetite-ilmenite pairs selected from the literature (Ghiorso 2008; Blundy et al. 2008; Jolles and Lange 2019). Only 450 magnetite-ilmenite compositions that passed the test are displayed. Heavy (middle) and other two lines represent the mean linear regression and error envelope $( \pm 2 \sigma)$, respectively. how WinMIgob can be used for magnetite and ilmenite calculations, molecular ulvöspinel-magnetite and ilmenite-hematite amounts by different approaches, magnetite-ilmenite geothermometers, log oxygen fugacity, as well as in estimation of $\triangle \mathrm{NNO}$ (Carmichael 1967; Anderson 1968; Powell and Powell 1977; Spencer and Lindsley 1981; Lindsley and Spencer 1982; Stormer 1983; Andersen and Lindsley 1985; Sauerzapf et al. 2008). Once the typed or loaded magnetite-ilmenite pairs are processed by clicking the Calculate icon (i.e., $\Sigma$ ) in the Data Entry Section window of program, all output parameters are displayed in columns 1-133 (see Tab. 1) of the Calculation Screen and in an output Excel file. Pressing the $\mathrm{Ctrl}+\mathrm{F}$ keys or clicking the Open File to Calculate option from the Calculate menu also executes the data processing for a selected data file with the extension of ". mi". Representative Fe-Ti oxides with their stoichiometric $\mathrm{Fe}_{2} \mathrm{O}_{3}$ and $\mathrm{FeO}$ contents (wt. \%), structural formulae (apfu), the sum of atomic molecular proportions, as well as molecular ulvöspinel, magnetite, ilmenite and hematite amounts by WinMIgob program are given in Tab. 2 (see Fig. 3). By clicking the Send results to Excel file icon in the Calculation Screen, all outputs can be stored in an Excel file (Output.xlsx) and then displayed by clicking the Open and edit Excel file

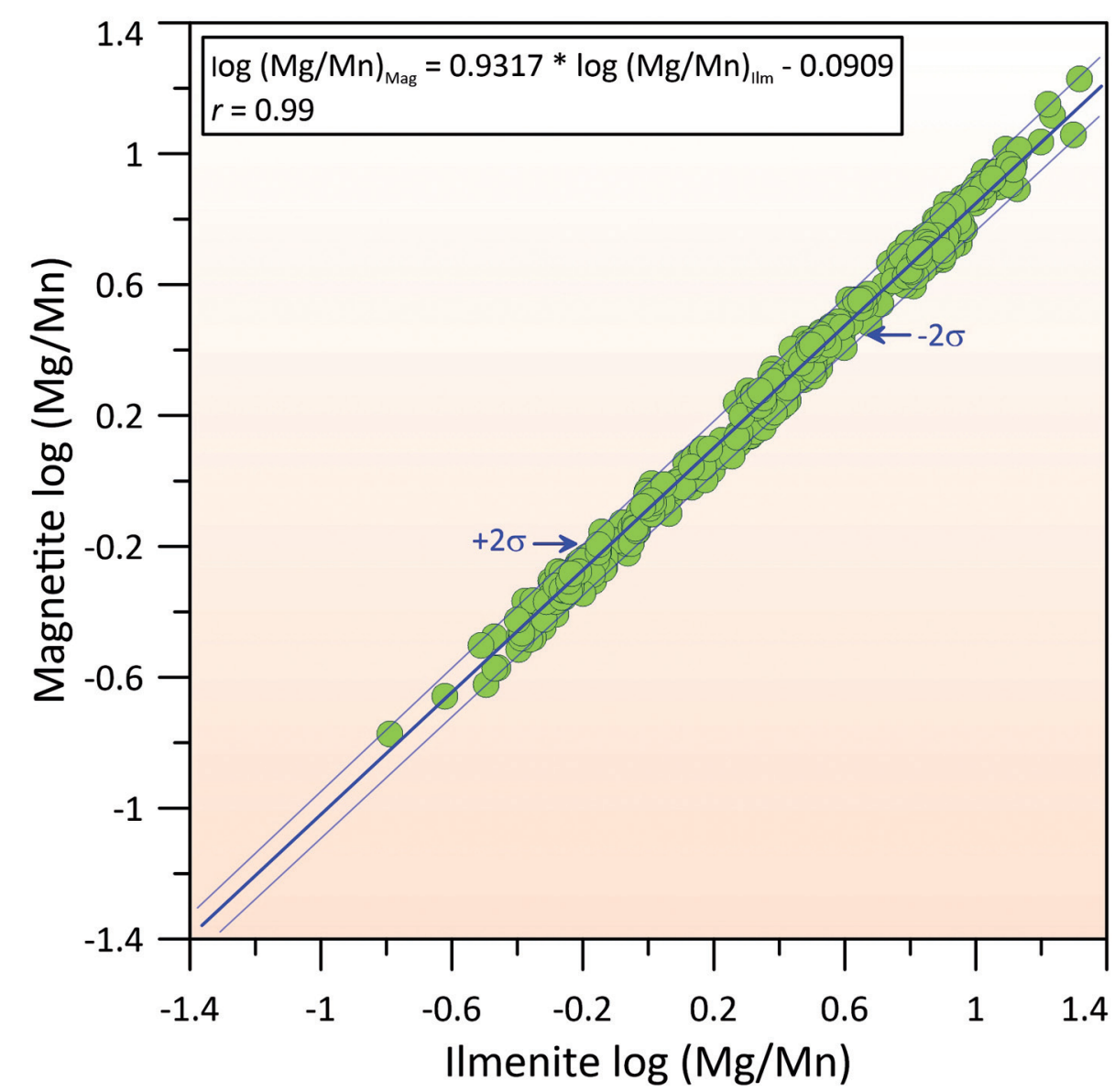


Tab. 2a Selected magnetite analyses (wt. \%) with their stoichiometric $\mathrm{Fe}_{2} \mathrm{O}_{3}$ and FeO contents (wt. \%), structural formulae (apfu), sum of atomic molecular proportions and molecular ulvöspinel and magnetite amounts by WinMIgob program

\begin{tabular}{|c|c|c|c|c|c|c|c|c|c|c|c|}
\hline Row & Magnetite & Mt1 & Mt2 & Mt3 & Mt4 & Mt5 & Mt6 & $\mathrm{Mt} 7$ & $\mathrm{Mt8}$ & Mt9 & Mt10 \\
\hline 1 & $\mathrm{SiO}_{2}$ & 0.10 & 0.02 & 0.30 & 0.00 & 0.06 & 0.07 & 0.14 & 0.18 & 0.12 & 0.09 \\
\hline 2 & $\mathrm{TiO}_{2}$ & 12.80 & 9.09 & 12.44 & 8.80 & 11.38 & 5.62 & 6.32 & 11.89 & 8.76 & 8.61 \\
\hline 3 & $\mathrm{Al}_{2} \mathrm{O}_{3}$ & 0.92 & 0.85 & 0.59 & 3.48 & 1.83 & 2.23 & 2.69 & 1.23 & 1.17 & 1.28 \\
\hline 4 & $\mathrm{~V}_{2} \mathrm{O}_{3}$ & 0.00 & 0.00 & 0.00 & 0.00 & 0.00 & 0.00 & 0.56 & 0.17 & 0.13 & 0.23 \\
\hline 5 & $\mathrm{Cr}_{2} \mathrm{O}_{3}$ & 0.00 & 0.01 & 0.00 & 0.00 & 0.00 & 0.00 & 0.03 & 0.04 & 0.02 & 0.02 \\
\hline 6 & $\mathrm{Fe}_{2} \mathrm{O}_{3}$ & 0.00 & 0.00 & 0.00 & 0.00 & 0.00 & 0.00 & 0.00 & 0.00 & 50.53 & 50.66 \\
\hline 7 & $\mathrm{FeO}$ & 80.80 & 82.60 & 77.68 & 79.60 & 78.67 & 85.27 & 82.94 & 78.24 & 37.97 & 37.68 \\
\hline 8 & $\mathrm{MnO}$ & 0.85 & 0.90 & 2.77 & 0.40 & 0.98 & 0.43 & 0.25 & 0.41 & 0.57 & 0.48 \\
\hline 9 & $\mathrm{NiO}$ & 0.00 & 0.00 & 0.00 & 0.00 & 0.00 & 0.00 & 0.00 & 0.02 & 0.00 & 0.00 \\
\hline 10 & $\mathrm{ZnO}$ & 0.18 & 0.20 & 0.00 & 0.07 & 0.00 & 0.00 & 0.15 & 0.50 & 0.00 & 0.00 \\
\hline 11 & $\mathrm{MgO}$ & 0.16 & 0.25 & 1.77 & 2.97 & 0.68 & 1.13 & 0.92 & 1.23 & 0.59 & 0.71 \\
\hline 12 & $\mathrm{CaO}$ & 0.01 & 0.00 & 0.00 & 0.00 & 0.00 & 0.00 & 0.21 & 0.02 & 0.01 & 0.02 \\
\hline 13 & $\mathrm{Na}_{2} \mathrm{O}$ & 0.00 & 0.00 & 0.00 & 0.00 & 0.00 & 0.00 & 0.03 & 0.04 & 0.00 & 0.00 \\
\hline 14 & $\mathrm{~K}_{2} \mathrm{O}$ & 0.00 & 0.00 & 0.00 & 0.00 & 0.00 & 0.00 & 0.00 & 0.03 & 0.00 & 0.00 \\
\hline 15 & $\sum($ wt. \%) & 95.82 & 93.92 & 95.55 & 95.32 & 93.60 & 94.75 & 94.24 & 94.00 & 99.87 & 99.78 \\
\hline 16 & $\mathrm{Fe}_{2} \mathrm{O}_{3}$ (calculated $)$ & 43.120 & 49.733 & 44.545 & 49.695 & 43.687 & 56.210 & 52.926 & 43.502 & 0.000 & 0.000 \\
\hline 17 & $\mathrm{FeO}($ calculated $)$ & 41.999 & 37.848 & 37.596 & 34.882 & 39.358 & 34.690 & 35.315 & 39.095 & 0.000 & 0.000 \\
\hline 18 & $\mathrm{Si}$ & 0.004 & 0.001 & 0.011 & 0.000 & 0.002 & 0.003 & 0.005 & 0.007 & 0.005 & 0.003 \\
\hline 19 & $\mathrm{Ti}$ & 0.363 & 0.262 & 0.350 & 0.242 & 0.328 & 0.158 & 0.179 & 0.340 & 0.249 & 0.245 \\
\hline 20 & $\mathrm{~V}$ & 0.041 & 0.038 & 0.026 & 0.150 & 0.083 & 0.098 & 0.119 & 0.055 & 0.052 & 0.057 \\
\hline 21 & $\mathrm{Cr}$ & 0.000 & 0.000 & 0.000 & 0.000 & 0.000 & 0.000 & 0.017 & 0.005 & 0.004 & 0.007 \\
\hline 22 & As & 0.000 & 0.000 & 0.000 & 0.000 & 0.000 & 0.000 & 0.001 & 0.001 & 0.001 & 0.001 \\
\hline 23 & $\mathrm{Fe}^{3+}$ & 1.225 & 1.435 & 1.252 & 1.366 & 1.258 & 1.581 & 1.496 & 1.246 & 1.437 & 1.440 \\
\hline 24 & $\mathrm{Fe}^{2+}$ & 1.326 & 1.214 & 1.175 & 1.066 & 1.259 & 1.084 & 1.110 & 1.244 & 1.200 & 1.191 \\
\hline 25 & $\mathrm{Mn}$ & 0.027 & 0.029 & 0.088 & 0.012 & 0.032 & 0.014 & 0.008 & 0.013 & 0.018 & 0.015 \\
\hline 26 & $\mathrm{Ni}$ & 0.000 & 0.000 & 0.000 & 0.000 & 0.000 & 0.000 & 0.000 & 0.001 & 0.000 & 0.000 \\
\hline 27 & $\mathrm{Zn}$ & 0.005 & 0.006 & 0.000 & 0.002 & 0.000 & 0.000 & 0.004 & 0.014 & 0.000 & 0.000 \\
\hline 28 & $\mathrm{Mg}$ & 0.009 & 0.014 & 0.099 & 0.162 & 0.039 & 0.063 & 0.052 & 0.070 & 0.033 & 0.040 \\
\hline 29 & $\mathrm{Ca}$ & 0.000 & 0.000 & 0.000 & 0.000 & 0.000 & 0.000 & 0.008 & 0.001 & 0.000 & 0.001 \\
\hline 30 & $\mathrm{Na}$ & 0.000 & 0.000 & 0.000 & 0.000 & 0.000 & 0.000 & 0.001 & 0.001 & 0.000 & 0.000 \\
\hline 31 & $\mathrm{~K}$ & 0.000 & 0.000 & 0.000 & 0.000 & 0.000 & 0.000 & 0.000 & 0.001 & 0.000 & 0.000 \\
\hline 32 & $\sum($ apfu $)$ & 3.000 & 3.000 & 3.000 & 3.000 & 3.000 & 3.000 & 3.000 & 3.000 & 3.000 & 3.000 \\
\hline 33 & $\mathrm{Usp}_{\mathrm{SAMP}}$ & 2.27 & 2.30 & 2.24 & 2.20 & 2.30 & 2.25 & 2.26 & 2.29 & 2.27 & 2.27 \\
\hline 34 & Usp (mol. \%) & 36.72 & 26.30 & 36.08 & 24.19 & 32.98 & 16.06 & 18.39 & 34.73 & 25.37 & 24.81 \\
\hline 35 & Mag (mol. \%) & 63.28 & 73.70 & 63.92 & 75.81 & 67.02 & 83.94 & 81.61 & 65.27 & 74.63 & 75.19 \\
\hline 36 & $X_{\text {Usp }}^{\prime}$ & 0.37 & 0.27 & 0.36 & 0.26 & 0.34 & 0.17 & 0.19 & 0.35 & 0.26 & 0.25 \\
\hline 37 & $X_{\text {Mag }}^{\text {Usp }}$ & 0.63 & 0.73 & 0.64 & 0.74 & 0.66 & 0.83 & 0.81 & 0.65 & 0.74 & 0.75 \\
\hline
\end{tabular}

Mt1-Il1 to Mt6-Il6 pairs from Ghiorso (2008); Mt7-I17 and Mt8-I18 from Blundy et al. (2008); Mt9-I19 and Mt10-Il10 from Jolles and Lange (2019); Usp - ulvöspinel, Mag - magnetite, Ilm - ilmenite, Hem - hematite (molecular ulvöspinel, magnetite, ilmenite and hematite amounts by the method of Carmichael 1967); SAMP - sum of atomic molecular proportion (from Lepage 2003); $X_{i}$ - mol fraction amount of $i$ (formulation from Sauerzapf et al. 2008)

icon or by selecting Open Excel File (Output.xlsx) option from the pull-down menu of Excel in the Calculation Screen window. All input and calculated parameters from an Output tab of an Excel file (i.e., Output.xlsx) are transposed automatically to the Transpose tab. This procedure provides the user to prepare a quick table for direct presentation and publication by using the copy and paste options. The validity of WinMIgob outputs in terms of magnetite-ilmenite geothermometer and oxygen barometer has been tested with 689 magnetiteilmenite pairs selected from literature (Ghiorso 2008; Blundy et al. 2008; Jolles and Lange 2019). However, only 450 of the total 689 magnetite and ilmenite compositions passed the Bacon and Hirschmann (1988) equilibrium test (Fig. 2).

\subsection{Magnetite-ilmenite geothermometer calbrations and oxygen barometers}

Buddington and Lindsley (1964) presented a graphical solution for the $\mathrm{Fe}-\mathrm{Ti}$ oxide geothermometer and oxygen barometer using the earlier experimental studies carried on cubic and rhombohedral Fe-Ti oxides. The technique takes into account the compositions of coexisting mag- 
WinMlgob: A Windows program for magnetite-ilmenite geothermometer and oxygen barometer

Tab. 2b Selected ilmenite analyses (wt. \%) with their stoichiometric $\mathrm{Fe}_{2} \mathrm{O}_{3}$ and FeO contents (wt. \%), structural formulae (apfu), sum of atomic molecular proportions and molecular ilmenite and hematite amounts by WinMIgob program

\begin{tabular}{|c|c|c|c|c|c|c|c|c|c|c|c|}
\hline & Ilmenite & Il1 & $\mathrm{I} 12$ & I13 & $\mathrm{I} 14$ & I15 & I16 & I17 & Il8 & I19 & Il10 \\
\hline 38 & $\mathrm{SiO}_{2}$ & 0.02 & 0.03 & 0.31 & 0.00 & 0.04 & 0.01 & 0.03 & 0.05 & 0.03 & 0.04 \\
\hline 39 & $\mathrm{TiO}_{2}$ & 48.30 & 49.34 & 47.22 & 38.50 & 48.49 & 41.35 & 46.40 & 43.12 & 45.84 & 45.27 \\
\hline 40 & $\mathrm{Al}_{2} \mathrm{O}_{3}$ & 0.04 & 0.06 & 0.00 & 0.50 & 0.11 & 0.24 & 0.24 & 0.15 & 0.08 & 0.12 \\
\hline 41 & $\mathrm{~V}_{2} \mathrm{O}_{3}$ & 0.00 & 0.00 & 0.00 & 0.00 & 0.00 & 0.00 & 0.37 & 0.08 & 0.12 & 0.28 \\
\hline 42 & $\mathrm{Cr}_{2} \mathrm{O}_{3}$ & 0.00 & 0.00 & 0.00 & 0.00 & 0.00 & 0.00 & 0.02 & 0.01 & 0.01 & 0.01 \\
\hline 43 & $\mathrm{Fe}_{2} \mathrm{O}_{3}$ & 0.00 & 0.00 & 0.00 & 0.00 & 0.00 & 0.00 & 0.00 & 0.00 & 13.77 & 15.20 \\
\hline 44 & $\mathrm{FeO}$ & 49.10 & 48.43 & 44.69 & 53.60 & 47.09 & 53.80 & 47.44 & 50.12 & 37.01 & 35.85 \\
\hline 45 & $\mathrm{MnO}$ & 1.58 & 1.84 & 3.81 & 0.37 & 1.59 & 0.60 & 0.39 & 0.54 & 1.10 & 0.86 \\
\hline 46 & $\mathrm{NiO}$ & 0.00 & 0.00 & 0.00 & 0.00 & 0.00 & 0.00 & 0.00 & 0.00 & 0.00 & 0.00 \\
\hline 47 & $\mathrm{ZnO}$ & 0.00 & 0.10 & 0.00 & 0.00 & 0.00 & 0.00 & 0.07 & 0.40 & 0.00 & 0.00 \\
\hline 48 & $\mathrm{MgO}$ & 0.40 & 0.63 & 3.02 & 3.61 & 1.31 & 1.86 & 1.76 & 2.21 & 1.31 & 1.51 \\
\hline 49 & $\mathrm{CaO}$ & 0.02 & 0.01 & 0.00 & 0.00 & 0.00 & 0.00 & 0.04 & 0.03 & 0.07 & 0.02 \\
\hline 50 & $\mathrm{Na}_{2} \mathrm{O}$ & 0.00 & 0.00 & 0.00 & 0.00 & 0.00 & 0.00 & 0.00 & 0.02 & 0.00 & 0.00 \\
\hline 51 & $\mathrm{~K}_{2} \mathrm{O}$ & 0.00 & 0.00 & 0.00 & 0.00 & 0.00 & 0.00 & 0.01 & 0.03 & 0.00 & 0.00 \\
\hline 52 & $\sum($ wt. $\%)$ & 99.46 & 100.44 & 99.05 & 96.58 & 98.63 & 97.86 & 96.77 & 96.76 & 99.34 & 99.16 \\
\hline 53 & $\mathrm{Fe}_{2} \mathrm{O}_{3}$ (calculated) & 8.853 & 7.887 & 12.318 & 28.645 & 8.188 & 22.798 & 10.363 & 18.049 & 0.000 & 0.000 \\
\hline 54 & $\mathrm{FeO}$ (calculated) & 41.134 & 41.333 & 33.606 & 27.823 & 39.722 & 33.286 & 38.115 & 33.879 & 0.000 & 0.000 \\
\hline 55 & $\mathrm{Si}$ & 0.001 & 0.001 & 0.008 & 0.000 & 0.001 & 0.000 & 0.001 & 0.001 & 0.001 & 0.001 \\
\hline 56 & $\mathrm{Ti}$ & 0.915 & 0.924 & 0.878 & 0.723 & 0.920 & 0.781 & 0.892 & 0.824 & 0.873 & 0.863 \\
\hline 57 & $\mathrm{~V}$ & 0.001 & 0.002 & 0.000 & 0.015 & 0.003 & 0.007 & 0.007 & 0.004 & 0.002 & 0.004 \\
\hline 58 & $\mathrm{Cr}$ & 0.000 & 0.000 & 0.000 & 0.000 & 0.000 & 0.000 & 0.008 & 0.002 & 0.002 & 0.006 \\
\hline 59 & As & 0.000 & 0.000 & 0.000 & 0.000 & 0.000 & 0.000 & 0.000 & 0.000 & 0.000 & 0.000 \\
\hline 60 & $\mathrm{Fe}^{3+}$ & 0.168 & 0.148 & 0.229 & 0.538 & 0.155 & 0.431 & 0.199 & 0.345 & 0.262 & 0.290 \\
\hline 61 & $\mathrm{Fe}^{2+}$ & 0.866 & 0.861 & 0.694 & 0.581 & 0.838 & 0.699 & 0.815 & 0.719 & 0.784 & 0.760 \\
\hline 62 & $\mathrm{Mn}$ & 0.034 & 0.039 & 0.080 & 0.008 & 0.034 & 0.013 & 0.008 & 0.012 & 0.024 & 0.018 \\
\hline 63 & $\mathrm{Ni}$ & 0.000 & 0.000 & 0.000 & 0.000 & 0.000 & 0.000 & 0.000 & 0.000 & 0.000 & 0.000 \\
\hline 64 & $\mathrm{Zn}$ & 0.000 & 0.002 & 0.000 & 0.000 & 0.000 & 0.000 & 0.001 & 0.007 & 0.000 & 0.000 \\
\hline 65 & $\mathrm{Mg}$ & 0.015 & 0.023 & 0.111 & 0.134 & 0.049 & 0.070 & 0.067 & 0.084 & 0.049 & 0.057 \\
\hline 66 & $\mathrm{Ca}$ & 0.001 & 0.000 & 0.000 & 0.000 & 0.000 & 0.000 & 0.001 & 0.001 & 0.002 & 0.001 \\
\hline 67 & $\mathrm{Na}$ & 0.000 & 0.000 & 0.000 & 0.000 & 0.000 & 0.000 & 0.000 & 0.000 & 0.000 & 0.000 \\
\hline 68 & $\mathrm{~K}$ & 0.000 & 0.000 & 0.000 & 0.000 & 0.000 & 0.000 & 0.000 & 0.000 & 0.000 & 0.000 \\
\hline 69 & $\sum(a p f u)$ & 2.000 & 2.000 & 2.000 & 2.000 & 2.000 & 2.000 & 2.000 & 2.000 & 2.000 & 2.000 \\
\hline 70 & $\mathrm{Ilm}_{\mathrm{SAMP}}$ & 1.51 & 1.50 & 1.48 & 1.50 & 1.51 & 1.51 & 1.54 & 1.53 & 1.52 & 1.52 \\
\hline 71 & $\operatorname{Ilm}(\mathrm{mol} . \%)$ & 91.55 & 92.52 & 88.55 & 72.34 & 92.07 & 78.11 & 89.28 & 82.49 & 87.40 & 86.44 \\
\hline 72 & Hem (mol. \%) & 8.45 & 7.48 & 11.45 & 27.66 & 7.93 & 21.89 & 10.72 & 17.51 & 12.60 & 13.56 \\
\hline 73 & $X_{\mathrm{Ilm}}^{\prime}$ & 0.91 & 0.92 & 0.86 & 0.68 & 0.92 & 0.76 & 0.89 & 0.81 & 0.86 & 0.84 \\
\hline 74 & $X_{\mathrm{Hem}}^{\prime}$ & 0.09 & 0.08 & 0.14 & 0.32 & 0.08 & 0.24 & 0.11 & 0.19 & 0.14 & 0.16 \\
\hline
\end{tabular}

Mt1-Il1 to Mt6-Il6 pairs from Ghiorso (2008); Mt7-Il7 and Mt8-Il8 from Blundy et al. (2008); Mt9-I19 and Mt10-Il10 from Jolles and Lange (2019); Usp - ulvöspinel, Mag - magnetite, Ilm - ilmenite, Hem - hematite (molecular ulvöspinel, magnetite, ilmenite and hematite amounts by the method of Carmichael 1967); SAMP - sum of atomic molecular proportion (from Lepage 2003); $X_{i}$ - mol fraction amount of $i$ (formulation from Sauerzapf et al. 2008)

netite-ulvöspinel (spinel phase) and ilmenite-hematite solid solution (rhombohedral phase) phases, defined as a mole fraction of ulvöspinel and a mole fraction of hematite, respectively. The magnetite-ilmenite geothermometer is based on the temperature-dependent exchange of $\mathrm{Fe}^{2+}+\mathrm{Ti}^{4+}$ for $2 \mathrm{Fe}^{3+}$ between magnetite- ulvöspinel and ilmenite-hematite endmembers, whereas the oxygen barometer considers an iron redox equilibrium, which may be formulated by the magnetite-hematite oxygen buffer equilibrium or by an equilibrium involving the Ti-rich endmembers of the two Fe-Ti oxide series (Sauerzapf et al. 2008).
The geothermometer and oxygen barometer within the concept of a graphical solution later have been reformulated on a thermodynamic basis using the earlier experimental data of Buddington and Lindsley (1964). For example, Powell and Powell (1977) used equilibrium thermodynamic methods to develop an independent $\mathrm{Fe}-\mathrm{Ti}$ oxide geothermometer and oxygen barometer (Fig. 4), differently, based on the experimental data of Buddington and Lindsley (1964). They presented Fe-Ti geothermometer and oxygen barometer both as graphically and with defined equations for coexisting magnetite and ilmenite solid solutions in $\mathrm{FeO}-\mathrm{Fe}_{2} \mathrm{O}_{3}-\mathrm{TiO}_{2}$ system. 


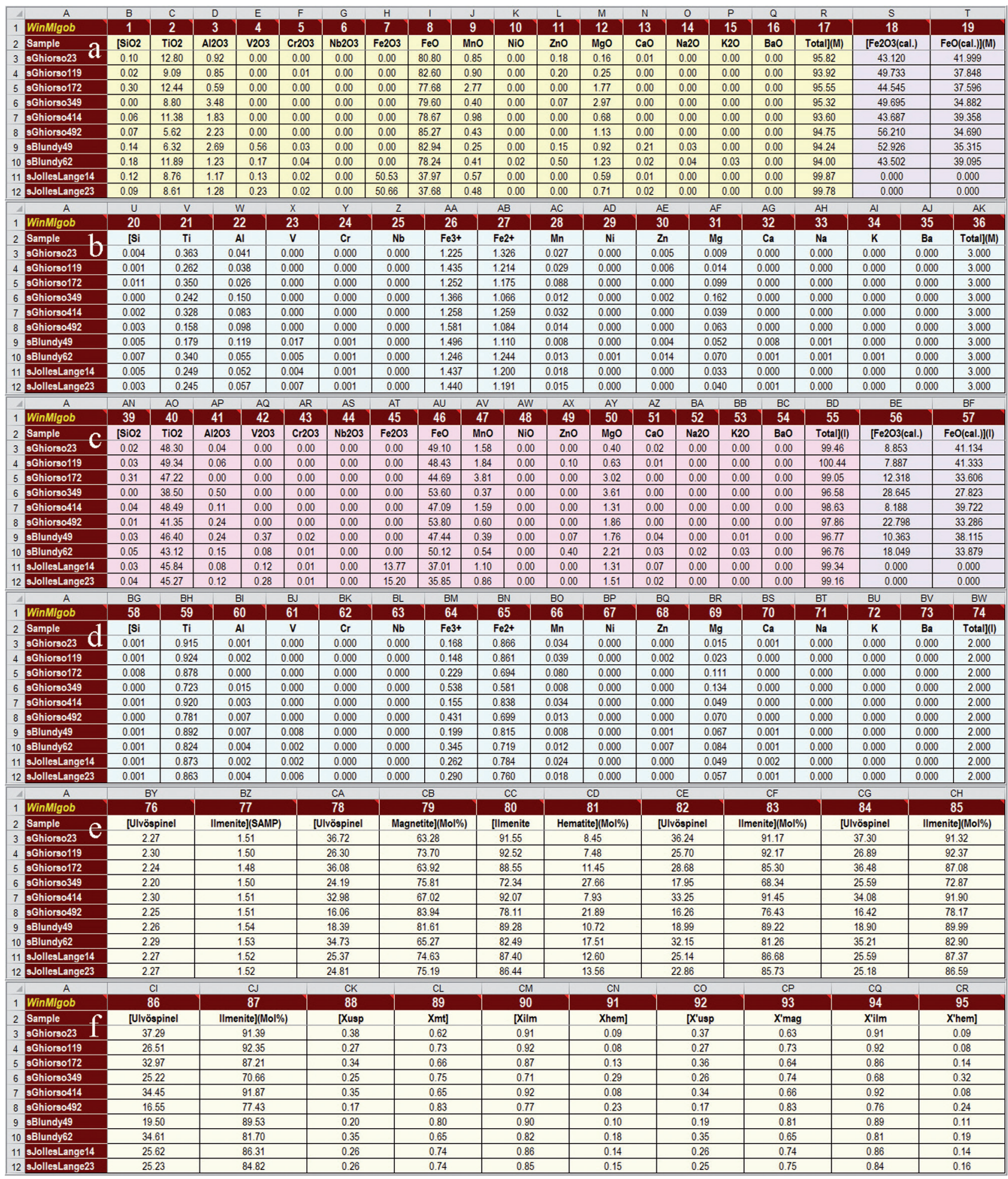

Fig. 3 Screenshots of an output Excel file (Output.xlsx) created by WinMIgob program showing all input and output parameters of magnetite-ilmenite compositions. a - Magnetite analyses with stoichiometric estimation of $\mathrm{Fe}_{2} \mathrm{O}_{3}$ and $\mathrm{FeO}$ (wt. \%) contents. b - Recalculated cations of magnetite mineral analyses $(a p f u)$. $\mathbf{c}$ - Ilmenite analyses with stoichiometric estimation of $\mathrm{Fe}_{2} \mathrm{O}_{3}$ and $\mathrm{FeO}$ (wt. \%) contents. d - Recalculated cations of ilmenite mineral analyses $(a p f u)$. e and $\mathbf{f}$ - Molecular ulvöspinel, magnetite, ilmenite and hematite amounts calculated by different methods (Carmichael 1967; Anderson 1968; Lindsley and Spencer 1982; Stormer 1983).

Although their model may fit for the NNO and the fayalite-magnetite-quartz (FMQ) buffer assemblages, it does not predict the results of experiments reflecting the more reducing buffer conditions such as the cobalt-co- 


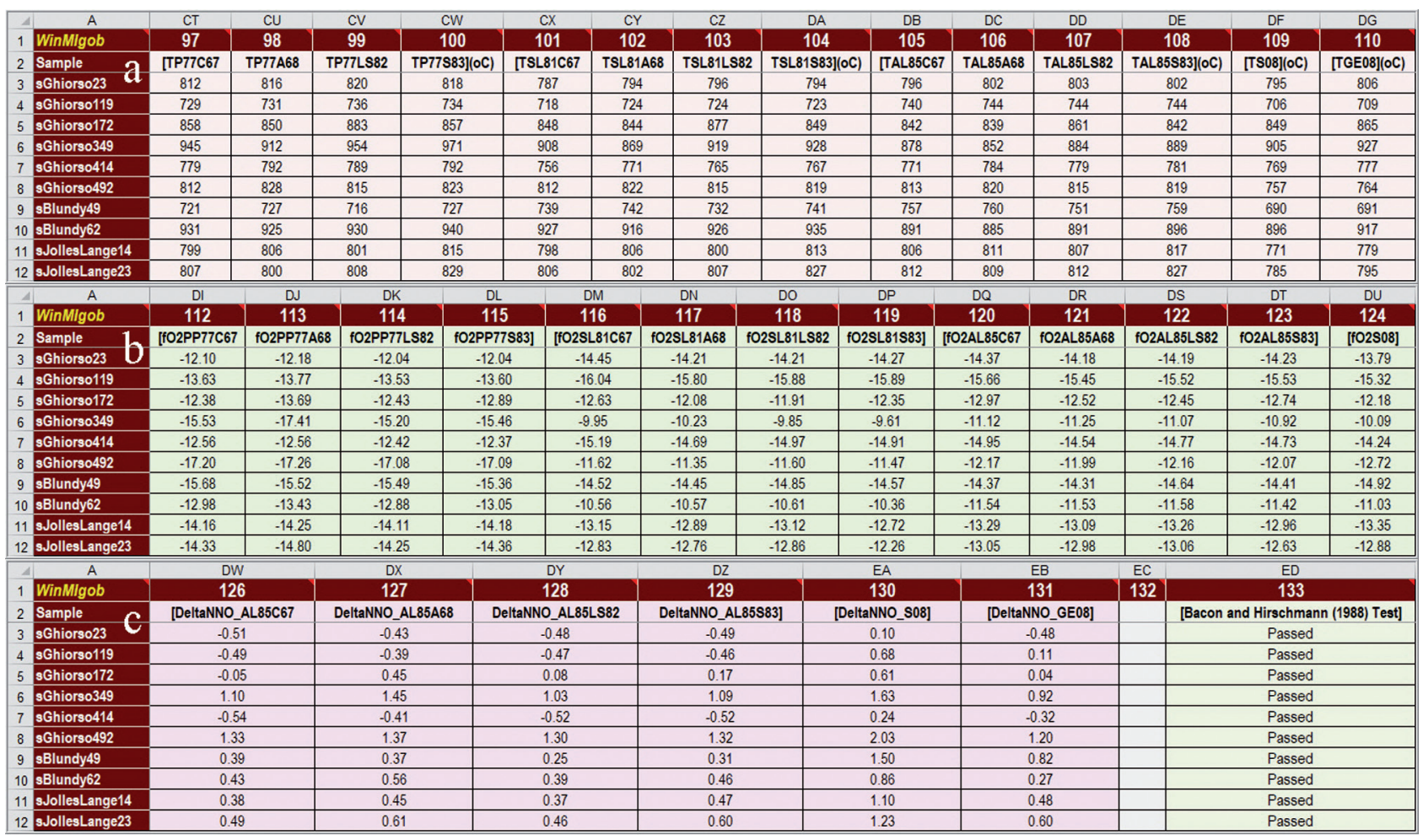

Fig. 4 Screenshots of an output Excel file (Output.xlsx) created by WinMIgob program for a various of magnetite-ilmenite; a - geothermometer, $\mathbf{b}$ - oxygen barometer and $\mathbf{c}$ - oxygen barometer relative to the nickel-nickel oxide buffer estimations.

balt oxide $(\mathrm{Co}-\mathrm{CoO})$ and the wustite-magnetite (WM) at low temperatures $\left(\sim 600-800^{\circ} \mathrm{C}\right)$ due to the increasing non-ideality of the solutions. Hence, Powell and Powell's (1977) calibration is only valid for a limited range of temperature and oxygen fugacity conditions (Spencer and Lindsley 1981). Powell and Powell (1977) also pointed out that significant departures in composition from the system $\mathrm{FeO}-\mathrm{Fe}_{2} \mathrm{O}_{3}-\mathrm{TiO}_{2}$ may show large uncertainties in the calculated temperature and activity of oxygen.

Spencer and Lindsley (1981) developed a solution model for coexisting magnetite-ulvöspinel and ilmenite-hematite solid solutions based on a least-squares fit of thermodynamic parameters to experimental data obtained at temperatures from 550 to $1200^{\circ} \mathrm{C}$. They applied their solution approach to Buddington and Lindsley's (1964) geothermometer and oxygen barometer model for coexisting magnetite-ilmenite pairs in a temperature-oxygen fugacity $\left(T-f \mathrm{O}_{2}\right)$ grid (Fig. 4). According to Spencer and Lindsley (1981), uncertainties in their model are approximately $40-80^{\circ} \mathrm{C}$ and $0.5-1.0 \log$ units $f \mathrm{O}_{2}$ in ulvöspinel and ilmenite compositions. Taking into account the most analyses of natural $\mathrm{Fe}-\mathrm{Ti}$ oxides that include small but significant amounts of minor components, Stormer (1983) proposed a new recalculation scheme, apart from the Carmichael's (1967) and Anderson's (1968) approach, based on the models of ionic substitution which is consistent with a thermodynamic model for the pure Fe-Ti system recommended by Spencer and Lindsley (1981).
However, the Stormer's (1983) scheme is more consistent with the model used by Spencer and Lindsley (1981) for fitting the experimental data and gives temperature and oxygen fugacity values falling in the middle of the range of variation with respect to the Carmichael's (1967) and Anderson's (1968) models.

Considering the inconsistent results, in addition to the compositional departures from the system $\mathrm{Fe}-\mathrm{Ti}-\mathrm{O}$, Andersen and Lindsley (1988) presented new experimental data on the compositions of coexisting magnetite-ilmenite pairs to revise the solution model for magnetite and ilmenite solid solutions by including the effects of $\mathrm{Mg}$ and $\mathrm{Mn}$, as well as examining the effects of orderdisorder on the solution properties of spinels. An internally consistent solution model by Andersen and Lindsley (1988) applies the linear programming based on a multicomponent Margules-type solution for ilmenite and an assumed Akimoto-type and available cation-distribution for magnetite solid solutions. They reported that in terms of the system $\mathrm{Fe}-\mathrm{Ti}-\mathrm{O}, T\left({ }^{\circ} \mathrm{C}\right)$ between 600 and $1200^{\circ} \mathrm{C}$ and $f \mathrm{O}_{2}$ between the NNO and WM buffers, there is little difference between these two models in calculated temperature and oxygen fugacity values.

Ghiorso and Sack (1991) developed a new thermodynamic formulation for the $\mathrm{Fe}-\mathrm{Ti}$ oxides which is calibrated models for spinel solid-solutions in the quinary system $\left(\mathrm{Fe}^{2+}, \mathrm{Mg}\right)\left(\mathrm{Al}, \mathrm{Fe}^{3+}, \mathrm{Cr}\right)_{2} \mathrm{O}_{4}-\left(\mathrm{Fe}^{2+}, \mathrm{Mg}\right)_{2} \mathrm{TiO}_{4}$ and rhombohedral oxides in the quaternary system $\left(\mathrm{Fe}^{2+}\right.$, 
$\mathrm{Mg}, \mathrm{Mn}) \mathrm{TiO}_{3}-\mathrm{Fe}_{2} \mathrm{O}_{3}$ that can be applied to the estimation of temperature and oxygen fugacity values for intermediate to silicic volcanic rocks to investigate the systematic of $T-\log f \mathrm{O}_{2}$ trends for various magmatic ferromagnesian-silicate assemblages. However, application of both the Andersen and Lindsley (1988) and Ghiorso and Sack (1991) formulations to Fe-Ti oxides in more oxidized magmas, such as in magmatic arcs, may give too high estimates of oxygen fugacity and temperatures, both too high and too low values depending on the range of $\log f_{2}$ (Evans and Scaillet 1997; Evans et al. 2006). For example, Lindsley and Frost (1992) noticed the users for Andersen and Lindsley's (1988) formulation at oxygen fugacities higher than two log bar units above those of the FMQ (i.e., at $\triangle \mathrm{FMQ}>2$ or $\triangle \mathrm{NNO}>1.3$ ). Lattard et al. (2005) synthesized assemblages of titanomagnetite-ilmenite, ilmenite-pseudobrookite and single-phase samples under a wide range of $f \mathrm{O}_{2}$ (in the range $\Delta \mathrm{NNO}-5$ to +5 ) in sub-solidus conditions, at $1 \mathrm{bar}$ and at temperatures between 1000 and $1300^{\circ} \mathrm{C}$, in the $\mathrm{Fe}-\mathrm{Ti}-\mathrm{O}$ system.

Considering unsatisfactory results of previous calibrations, especially at high temperature and low to moderate oxygen fugacity conditions that point out the crystallization of basic and intermediate rocks, Sauerzapf et al. (2008) presented a new version of magnetite-ilmenite geothermometer and oxygen barometer (Fig. 4) based on the numerical fits of a large experimental dataset, nearly 200 , in the $\mathrm{Fe}-\mathrm{Ti}-\mathrm{Al}-\mathrm{Mg}-\mathrm{O}$ system and those of literature studies. Sauerzapf et al. (2008) recognized that their subsolidus experimental results at temperatures in the range $1100-1300^{\circ} \mathrm{C}$ and under low to moderate $\mathrm{fO}_{2}$ (i.e., $-4<\Delta \mathrm{NNO}<+2$ ) conditions with the addition of $\mathrm{Mg}$ and/or $\mathrm{Al}$ in the concentration ranges can be accommodated by simple projections. Thus, by applying numerical fits to those cited projections, they generated empirical formulations to retrieve temperature values from $X_{\text {usp }}^{\prime}$ and $X_{\text {ilm }}^{\prime}$ (i.e., projected mole fractions) of titanomagnetite-ilmenite solid solution pairs and oxygen fugacity values from $X_{\text {usp }}^{\prime}$ and $T\left({ }^{\circ} \mathrm{C}\right)$ relationship. According to Sauerzapf et al. (2008), tests carried on the independent experimental results indicate that their model reproduces the experimental temperatures generally within $\pm 70^{\circ} \mathrm{C}$, and in most cases within $\pm 50^{\circ} \mathrm{C}$, as well as the oxygen fugacity values usually within $\pm 0.4 \log$ units. When compared to the Andersen and Lindsley (1988) and Ghiorso and Sack (1991) models, their formulations yield substantial temperature underestimates for assemblages equilibrated at temperatures $>950^{\circ} \mathrm{C}$ under moderate to low $f \mathrm{O}_{2}$ values (i.e., $\Delta \mathrm{NNO} \leq 0$ ). Thus, the Sauerzapf et al. (2008) formulations may give reliable results in estimating the magmatic temperature and oxygen fugacity conditions for rapidly cooled intermediate to basic igneous systems.
WinMIgob calculates the temperatures of Sauerzapf et al. (2008) model $\left(X_{\mathrm{ilm}}^{\prime}=f\left(X_{\text {usp }}^{\prime}, T\right)\right)$ through least-squares method using a series of third-order polynomial functions (Fig. 5a). Formulations used in the program's structure indicate that the calculated temperature values, in the range $700-1300^{\circ} \mathrm{C}$, by WinMIgob reproduce the Sauerzapf et al. (2008) model within $\pm 19^{\circ} \mathrm{C}$ for 450 magnetite-ilmenite pairs reported in the literature from volcanic rocks that are primarily dacitic and rhyolitic composition. Consequently, WinMIgob calculates the Fe-Ti oxide geothermometer of Sauerzapf et al. (2008) model with a high correlation $(r=0.99)$ coefficient (Fig. 5b). On the other hand, the estimates of oxygen fugacity relative to the $\mathrm{NNO}(\Delta \mathrm{NNO})$ by program are mostly within \pm 0.06 units (Fig. $5 \mathrm{c}$ ), and there also exists a high correlation coefficient $(r=0.99)$ between the Sauerzapf et al. (2008) calibration and WinMIgob outputs (Fig. 5d).

Because of the magnetite-ilmenite geothermobarometer of Ghiorso and Sack (1991) has been found to overestimate the temperature and oxygen fugacity in most moderate- to highly-oxidized calc-alkaline magma series (e.g., Mt. Pinatubo dacitic magma), as well as collected high-quality cation-ordering data for hematite-ilmenite solid solutions along the $\mathrm{Fe}_{2} \mathrm{O}_{3}-\mathrm{FeTiO}_{3}$ join since then, a new thermodynamic model for rhombohedral oxide solid solutions in the system $\mathrm{Fe}_{2} \mathrm{O}_{3}-\mathrm{FeTiO}_{3}-\mathrm{MgTiO}_{3}-\mathrm{MnTiO}_{3}$ containing minor amounts of $\mathrm{Al}_{2} \mathrm{O}_{3}$ was developed by Ghiorso and Evans (2008) to revise and correct the earlier $\mathrm{Fe}-\mathrm{Ti}$ oxides geothermometer and oxygen barometer calibration. The model was applied by Ghiorso and Evans (2008) to a newly compiled dataset of natural $\mathrm{Fe}-\mathrm{Ti}$ oxide pairs from silicic volcanic rocks, and results were compared to previous formulations. The general conclusion is that their current model gives a better estimate of the oxidation state for magmas that equilibrated under conditions more oxidizing than the NNO buffer. On the other hand, temperatures obtained from the Ghiorso and Evans (2008) model are also found to be consistent with experimental phase relations for the stability of cummingtonite in silicic volcanic rocks. According to Ghiorso and Evans (2008), the results of their geothermometer and oxygen barometer differ from previously calibrated $\mathrm{Fe}-\mathrm{Ti}$ oxide pairs formulations (e.g., Andersen and Lindsley 1988; Ghiorso and Sack 1991), most notably in the estimation of oxidation state under relatively oxidized conditions $(>\mathrm{NNO}+1)$.

WinMIgob provides the users to estimate Ghiorso and Evans (2008) Fe-Ti oxides geothermometer by using a linear regression equation $\left[T_{\mathrm{GE} 08}\left({ }^{\circ} \mathrm{C}\right)=1.098258692 \times T\right.$ ${ }_{\text {s08 }}-67.18937519$ ] correlating the Sauerzapf et al. (2008) and Ghiorso and Evans (2008) calibrations (Fig. 6a). Although a high correlation $(r=0.99)$ exists between these two calibrations, the users should be careful when using 

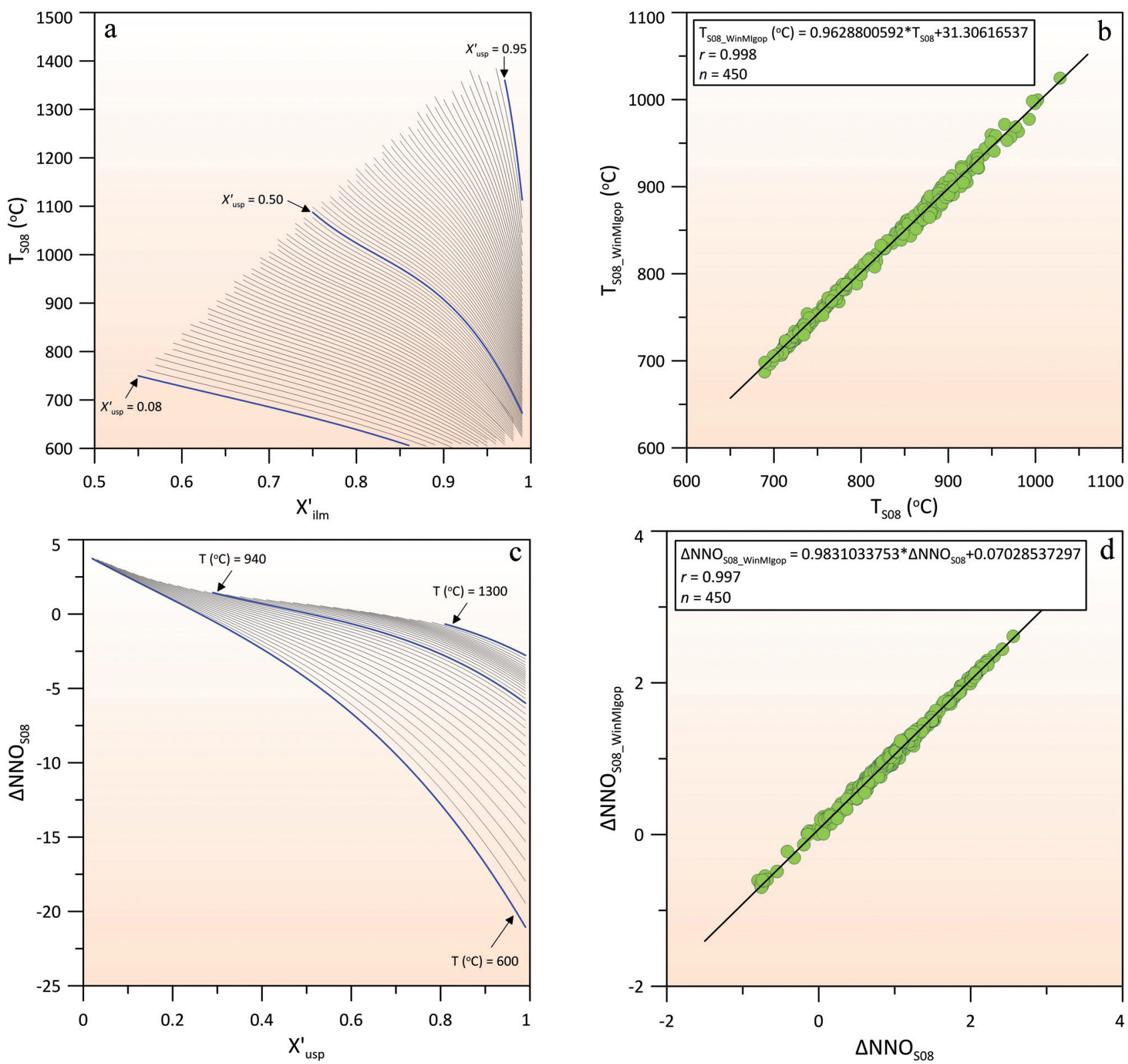

Fig. $5 \mathbf{a}-X_{\text {ilm }}^{\prime}-T\left({ }^{\circ} \mathrm{C}\right)$ relationship for $X_{\text {ws }}^{\prime}$ values between 0.08 and 0.95 using the third-order polynomial functions to estimate the temperature of Sauerzapf et al. (2008) model. b - Temperature relationship between the Sauerzapf et al. (2008) model and WinMIgob program. $\mathbf{c}-X_{\text {usp }}^{\prime}-\Delta N N O$ relationship for temperature values between 600 and $1300{ }^{\circ} \mathrm{C}$ using the third-order polynomial functions to estimate $\Delta$ NNO of the Sauerzapf et al. (2008) model. d $-\triangle$ NNO relationship between the Sauerzapf et al. (2008) model and WinMIgob program.

WinMIgob's output for the Ghiorso and Evans (2008) geothermometer in their own studies especially for temperatures $<700^{\circ} \mathrm{C}$ and $>950^{\circ} \mathrm{C}$. When compared to the magnetite-ilmenite geothermometer, the $\triangle \mathrm{NNO}$ values in these two calibrations show much more variations, with a lower correlation $(r=0.83)$ coefficient (Fig. 6b) and should also be used with caution by the WinMIgob's users. In terms of the $\triangle \mathrm{NNO}$ values, there is a high correlation coefficient $(r=0.95)$ between the Andersen and Lindsley (1985) and Ghiorso and Evans (2008) calibrations (Fig. 6c). Thus, by selecting the second option from the pull-down menu of Oxygen barometer (see Fig. 1e) this relationship may be used by the program's users in the estimation of the $\triangle \mathrm{NNO}$ values by Ghiorso and Evans (2008). The current version of WinMIgop provides the users to display ten diagrams by using the Grapher program for coexisting magnetite-ilmenite compositions. Some of selected diagram types from the pull-down menu of Graph in the Calculation Screen are given in Fig. 7.

In this study, magnetite-ilmenite analyses that present both $\mathrm{Fe}_{2} \mathrm{O}_{3}$ and $\mathrm{FeO}$ (wt. \%) were tested with $\mathrm{FeO}_{\text {tot }}$ (wt. \%) contents, estimated from $\mathrm{FeO}+0.8998 \mathrm{Fe}_{2} \mathrm{O}_{3}$, to obtain $T\left({ }^{\circ} \mathrm{C}\right)$ and $f \mathrm{O}_{2}$ values using different calibrations. Magnetite-ilmenite analyses with $\mathrm{Fe}_{2} \mathrm{O}_{3}$ and $\mathrm{FeO}$ (wt. \%) 

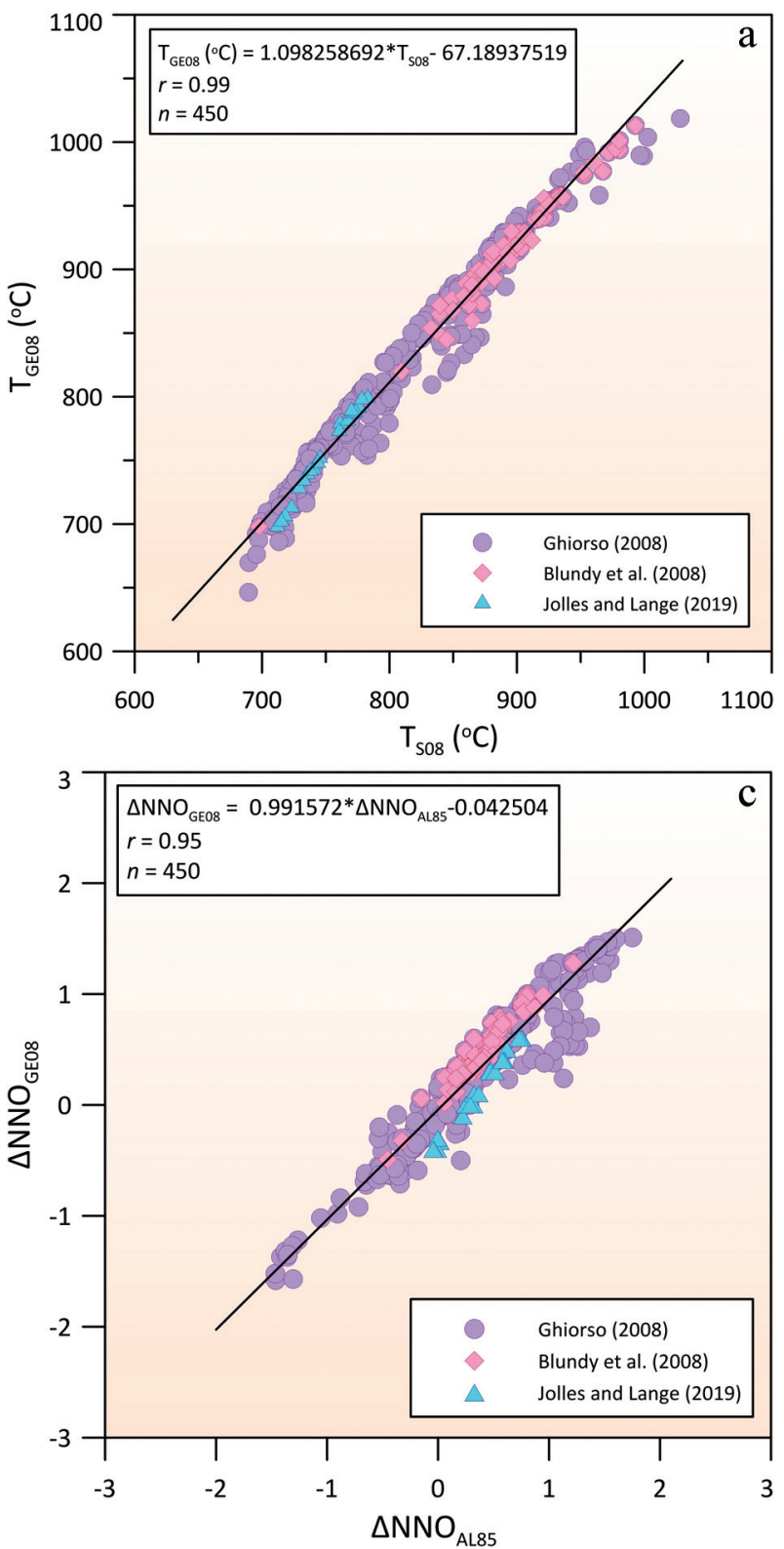

compositions from the literature (Himmelberg and Ford 1977; Stormer (1983); Honjo et al. 1992; Venezky and Rutherford 1999; Mullen and McCallum 2013; Ondrejka et al. 2015) were first checked for the Bacon-Hirschmann equilibrium test by WinMIgop program. Then magnetiteilmenite pairs that passed the test were subjected to both ferric and ferrous and total iron calculations to estimate $T\left({ }^{\circ} \mathrm{C}\right)$ and $f \mathrm{O}_{2}$ values for different calibration methods (e.g., Anderson and Lindsley (1985); Sauerzapf et al. 2008). Finally, a comparison indicates that the resultant values of $T\left({ }^{\circ} \mathrm{C}\right)$ and $f \mathrm{O}_{2}$ show no important variations, at least selected for magnetite-ilmenite analyses from the literature, in terms of allocation of ferric and ferrous electron-probe data in which total iron content is available (ESM 2).

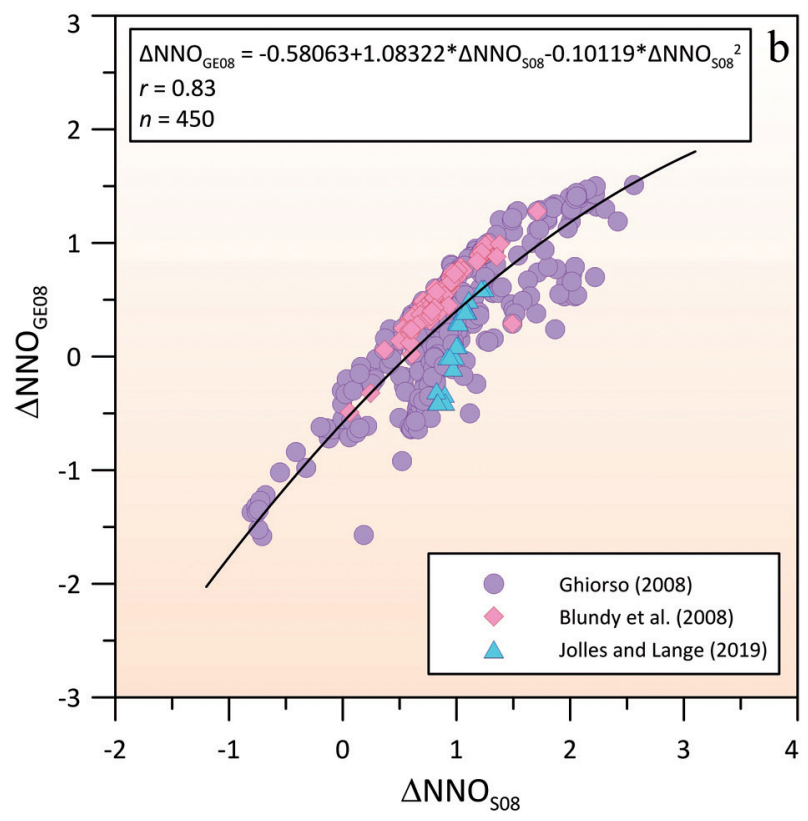

Fig. 6a $-T_{\mathrm{S} 08}-T_{\mathrm{GE} 08}\left({ }^{\circ} \mathrm{C}\right)$ relationship between the magnetite-ilmenite geothermometer calibrations by Sauerzapf et al. (2008) and Ghiorso and Evans (2008) for the selected 450 magnetite and ilmenite analyses from the literature. $\mathbf{b}-\Delta \mathrm{NNO}_{\mathrm{S} 08}-\Delta \mathrm{NNO}_{\mathrm{GE} 08}$ relationship between magnetite-ilmenite $\triangle \mathrm{NNO}$ estimations by the Sauerzapf et al. (2008) and Ghiorso and Evans (2008) models. $\mathbf{c}-\Delta \mathrm{NNO}_{\mathrm{AL} 85}-\Delta \mathrm{NNO}_{\mathrm{GEO}}$ relationship between magnetite-ilmenite $\triangle \mathrm{NNO}$ estimations by the Andersen and Lindsley (1985) and Ghiorso and Evans (2008) models.

\section{Summary and availability of the program}

WinMIgob is a user-friendly package for compositions of magnetite-ilmenite pairs, which is developed for personal computers running in the Windows operating system. The program calculates structural formulae of multiple magnetite and ilmenite analyses, obtained both from wet-chemical and electron-microprobe techniques, based on different ferric iron estimation methods. WinMIgob generates two main windows. The first window (i.e., Data Entry Screen) appears on the screen with several pull-down menus and equivalent shortcuts. By selecting options or clicking buttons on the start-up screen, the user can enter or load magnetite and ilmenite analyses into the data entry section and make necessary arrangements for a 

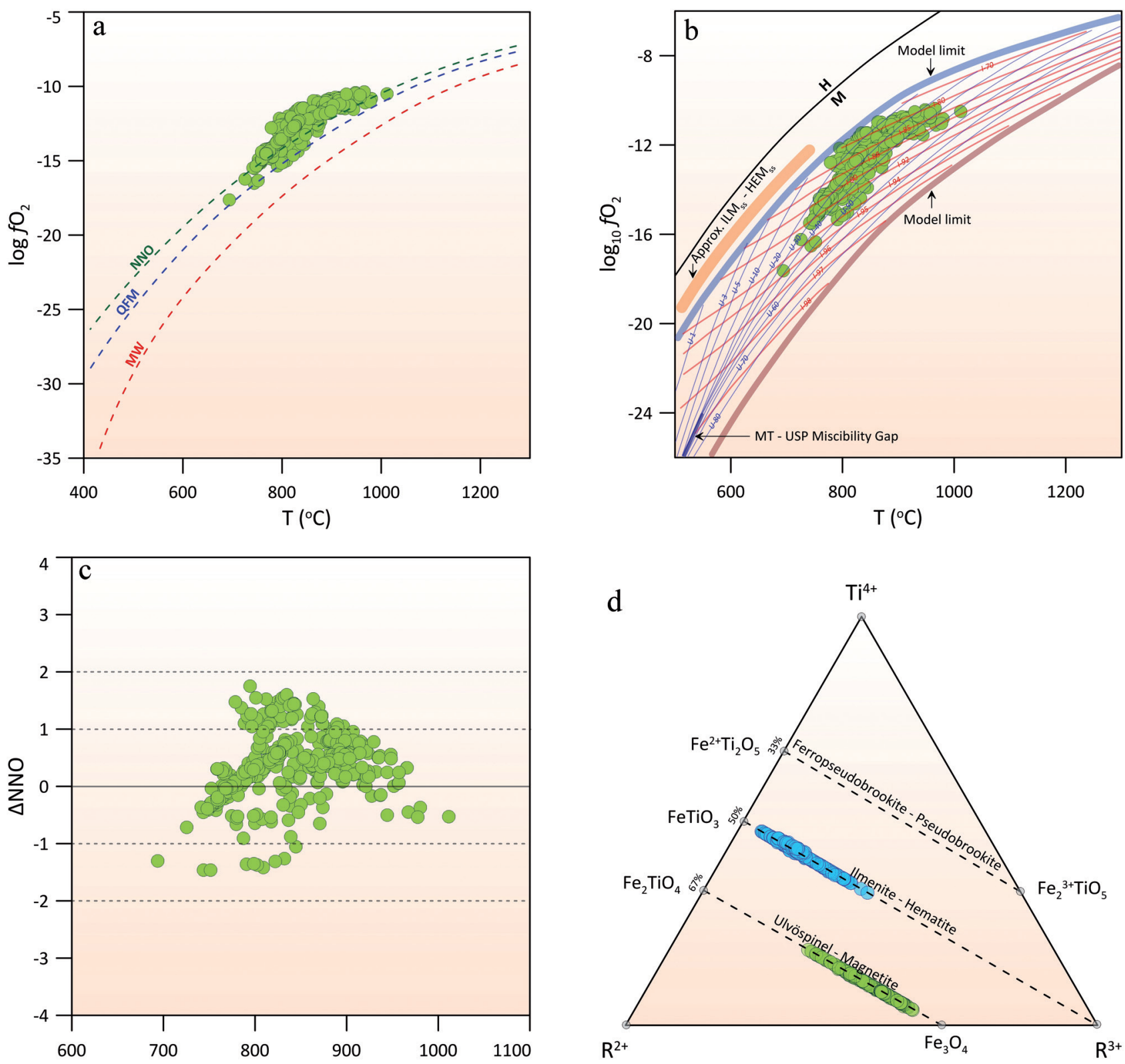

Fig. 7 a - Distribution of selected Fe-Ti oxides from the literature ( $n=450$; Ghiorso 2008; Blundy et al. 2008; Jolles and Lange 2019$)$ in $T\left({ }^{\circ} \mathrm{C}\right)-f \mathrm{O}_{2}$ plot using the calibration of Andersen and Lindsley (1985). Oxygen buffer curves are taken from Himmelberg and Ford (1977). NNO = nickel-nickel oxide, QFM = quartz-fayalite-magnetite, $\mathrm{MW}=$ magnetite-wüstite. $\mathbf{b}$ - Distribution of selected Fe-Ti oxides in Spencer and Lindsley (1981) $T\left({ }^{\circ} \mathrm{C}\right)-f \mathrm{O}_{2}$ grid. $\mathbf{c}-T\left({ }^{\circ} \mathrm{C}\right)-\Delta \mathrm{NNO}$ plot using the calibration of Andersen and Lindsley (1985) and calculation method by Stormer (1983) for Fe-Ti oxides dataset. $\mathbf{d}-$ Compositions of $\mathrm{Fe}-\mathrm{Ti}$ oxides in $\mathrm{Ti}-\mathrm{R}^{2+}-\mathrm{R}^{3+}$ ternary diagram. $\mathrm{R}^{2+}=\mathrm{Fe}^{2+}+\mathrm{Mg}+\mathrm{Mn}+( \pm \mathrm{Zn} \pm \mathrm{Ni} \pm \mathrm{Ca} \pm \mathrm{Ba}), \mathrm{R}^{3+}=\mathrm{Fe}{ }^{3+}+\mathrm{Cr}+\mathrm{V}+\mathrm{Al}$. Dashed lines show high-temperature solid-solutions (magnetite-ulvöspine, hematite-ilmenite, pseudobrookite-ferropseudobrookite).

desired calculation scheme on the toolbar. By clicking the Calculate icon (i.e., $\Sigma$ ) on the toolbar in the Data Entry Screen window, all calculated parameters are displayed in the second window. The second window (i.e., Calculation Screen) allows the user to display all the input and results of cations (apfu) with stoichiometric ferric and ferrous iron contents, molecular magnetite-ulvöspinel and ilmenite-hematite amounts, magnetite-ilmenite geothermometers, oxygen barometers, oxygen fugacities relative to the NNO buffer and Bacon-Hirschmann equilibrium test. WinMIgob reports the output in a tabulated form with columns numbered from 1 to 133 in the Calculation Screen window, as well as in an Excel file. All the estimated magnetite and ilmenite data in the Calculation Screen can be sent to a Microsoft Excel file (i.e., Output.xlsx) and then this file can be used for further data manipulation, graphing and preparing a quick table for publication and presentation purposes. WinMIgob displays calculated magnetite and ilmenite compositions in binary and ternary diagrams, which can be viewed 
Tab. 3 Magnetite-ilmenite geothermometer and oxygen barometer estimations by WinMIgob program

\begin{tabular}{|c|c|c|c|c|c|c|c|c|c|c|c|}
\hline \multirow[t]{2}{*}{ Row } & & Mt1 & $\mathrm{Mt} 2$ & $\mathrm{Mt3}$ & $\mathrm{Mt} 4$ & Mt5 & Mt6 & Mt7 & Mt8 & Mt9 & Mt10 \\
\hline & \multicolumn{11}{|c|}{ Magnetite-ilmenite geothermometers $\left(T,{ }^{\circ} \mathrm{C}\right)$} \\
\hline 1 & $T_{\mathrm{P} 77 \mathrm{C} 67}$ & 812 & 729 & 858 & 945 & 779 & 812 & 721 & 931 & 799 & 807 \\
\hline 2 & $T_{\mathrm{P} 77 \_\mathrm{A} 68}$ & 816 & 731 & 850 & 912 & 792 & 828 & 727 & 925 & 806 & 800 \\
\hline 3 & $T_{\mathrm{P} 77 \mathrm{LS} 82}$ & 820 & 736 & 883 & 954 & 789 & 815 & 716 & 930 & 801 & 808 \\
\hline 4 & $T_{\mathrm{P} 77 \mathrm{~s} 83}$ & 818 & 734 & 857 & 971 & 792 & 823 & 727 & 940 & 815 & 829 \\
\hline 5 & $T_{\mathrm{SL} 81 \mathrm{C} 67}$ & 787 & 718 & 848 & 908 & 756 & 812 & 739 & 927 & 798 & 806 \\
\hline 6 & $T_{\text {SL81 A68 }}$ & 794 & 724 & 844 & 869 & 771 & 822 & 742 & 916 & 806 & 802 \\
\hline 7 & $T_{\mathrm{SL} 81 \mathrm{LS} 822}$ & 796 & 724 & 877 & 919 & 765 & 815 & 732 & 926 & 800 & 807 \\
\hline 8 & $T_{\mathrm{SL} 81 \mathrm{~S} 83}$ & 794 & 723 & 849 & 928 & 767 & 819 & 741 & 935 & 813 & 827 \\
\hline 9 & $T_{\mathrm{AL} 85 \mathrm{C} 67}$ & 796 & 740 & 842 & 878 & 771 & 813 & 757 & 891 & 806 & 812 \\
\hline 10 & $T_{\text {AL85_A68 }}$ & 802 & 744 & 839 & 852 & 784 & 820 & 760 & 885 & 811 & 809 \\
\hline 11 & $T_{\mathrm{AL} 85 \mathrm{LS} 822}$ & 803 & 744 & 861 & 884 & 779 & 815 & 751 & 891 & 807 & 812 \\
\hline 12 & $T_{\mathrm{AL} 85 \mathrm{~S} 83}$ & 802 & 744 & 842 & 889 & 781 & 819 & 759 & 896 & 817 & 827 \\
\hline 13 & $T_{\mathrm{S} 08 \mathrm{~A}}$ & 795 & 706 & 849 & 905 & 769 & 757 & 690 & 896 & 771 & 785 \\
\hline 14 & $T_{\mathrm{GE} 08 \_\mathrm{A}}$ & 806 & 709 & 865 & 927 & 777 & 764 & 691 & 917 & 779 & 795 \\
\hline 15 & $T_{\text {S08_A_AL85 }}$ & 771 & 693 & 825 & 888 & 743 & 793 & 713 & 896 & 791 & 804 \\
\hline 16 & $T_{\mathrm{GE}}$ & 774 & 687 & 835 & 904 & 743 & 799 & 710 & 914 & 796 & 811 \\
\hline 17 & $T_{\mathrm{S} 08 \mathrm{~B}}$ & 790 & 708 & 847 & 896 & 766 & 753 & 698 & 890 & 761 & 772 \\
\hline \multirow[t]{2}{*}{18} & $T_{\mathrm{GEO} O \mathrm{~B}}$ & 804 & 698 & 849 & 927 & 772 & 763 & 698 & 919 & 779 & 787 \\
\hline & \multicolumn{11}{|c|}{ Log oxygen fugacity $\left(f \mathrm{O}_{2}\right)$ values } \\
\hline 19 & $f \mathrm{O}_{2 \text { PP77_C67 }}$ & -12.10 & -13.63 & -12.38 & -15.53 & -12.56 & -17.20 & -15.68 & -12.98 & -14.16 & -14.33 \\
\hline 20 & $f \mathrm{O}_{2 \text { PP77 A68 }}$ & -12.18 & -13.77 & -13.69 & -17.41 & -12.56 & -17.26 & -15.52 & -13.43 & -14.25 & -14.80 \\
\hline 21 & $f \mathrm{O}_{2 \text { PP77 LS82 }}$ & -12.04 & -13.53 & -12.43 & -15.20 & -12.42 & -17.08 & -15.49 & -12.88 & -14.11 & -14.25 \\
\hline 22 & $f \mathrm{O}_{2 \mathrm{PP} 77 \mathrm{~S} 83}$ & -12.04 & -13.60 & -12.89 & -15.46 & -12.37 & -17.09 & -15.36 & -13.05 & -14.18 & -14.36 \\
\hline 23 & $f \mathrm{O}_{2 \mathrm{SL} 81 \mathrm{C} 67}$ & -14.45 & -16.04 & -12.63 & -9.95 & -15.19 & -11.62 & -14.52 & -10.56 & -13.15 & -12.83 \\
\hline 24 & $f \mathrm{O}_{2 \mathrm{SL} 81 \mathrm{~A} 68}$ & -14.21 & -15.80 & -12.08 & -10.23 & -14.69 & -11.35 & -14.45 & -10.57 & -12.89 & -12.76 \\
\hline 25 & $f \mathrm{O}_{2 \mathrm{SL} 81 \mathrm{LS} 82}$ & -14.21 & -15.88 & -11.91 & -9.85 & -14.97 & -11.60 & -14.85 & -10.61 & -13.12 & -12.86 \\
\hline 26 & $f \mathrm{O}_{2 \mathrm{SL} 81 \mathrm{~S} 83}$ & -14.27 & -15.89 & -12.35 & -9.61 & -14.91 & -11.47 & -14.57 & -10.36 & -12.72 & -12.26 \\
\hline 27 & $f \mathrm{O}_{2 \mathrm{AL} 85 \mathrm{C} 67}$ & -14.37 & -15.66 & -12.97 & -11.12 & -14.95 & -12.17 & -14.37 & -11.54 & -13.29 & -13.05 \\
\hline 28 & $f \mathrm{O}_{2 \mathrm{AL} 85 \mathrm{~A} 68}$ & -14.18 & -15.45 & -12.52 & -11.25 & -14.54 & -11.99 & -14.31 & -11.53 & -13.09 & -12.98 \\
\hline 29 & $f \mathrm{O}_{2 \mathrm{AL} 85 \mathrm{LS} 82}$ & -14.19 & -15.52 & -12.45 & -11.07 & -14.77 & -12.16 & -14.64 & -11.58 & -13.26 & -13.06 \\
\hline 30 & $f \mathrm{O}_{2 \mathrm{AL} 85 \mathrm{~S} 83}$ & -14.23 & -15.53 & -12.74 & -10.92 & -14.73 & -12.07 & -14.41 & -11.42 & -12.96 & -12.63 \\
\hline 31 & $f \mathrm{O}_{2 \mathrm{~s}} 08 \mathrm{~A}$ & -13.79 & -15.32 & -12.18 & -10.09 & -14.24 & -12.72 & -14.92 & -11.03 & -13.35 & -12.88 \\
\hline 32 & $f \mathrm{O}_{2}$ S08 A AL85 & -14.45 & -15.14 & -13.08 & -10.33 & -14.76 & -12.23 & -14.56 & -11.23 & -13.33 & -12.95 \\
\hline \multirow[t]{2}{*}{33} & $f \mathrm{O}_{2 \operatorname{ses} B}$ & -13.99 & -15.35 & -12.33 & -10.41 & -14.41 & -12.85 & -14.72 & -11.26 & -13.66 & -13.33 \\
\hline & \multicolumn{11}{|c|}{ Log oxygen fugacity values relative to the nickel-nickel oxide buffer $(\triangle \mathrm{NNO})$} \\
\hline 34 & $\Delta \mathrm{NNO}_{\mathrm{AL} 85 \mathrm{C} 67}$ & -0.51 & -0.49 & -0.05 & 1.10 & -0.54 & 1.33 & 0.39 & 0.43 & 0.38 & 0.49 \\
\hline 35 & $\Delta \mathrm{NNO}_{\mathrm{AL} 85 \_\mathrm{A} 68}$ & -0.43 & -0.39 & 0.45 & 1.45 & -0.41 & 1.37 & 0.37 & 0.56 & 0.45 & 0.61 \\
\hline 36 & $\Delta \mathrm{NNO}_{\mathrm{AL} 85 \mathrm{LS} 82}$ & -0.48 & -0.47 & 0.08 & 1.03 & -0.52 & 1.30 & 0.25 & 0.39 & 0.37 & 0.46 \\
\hline 37 & $\Delta \mathrm{NNO}_{\mathrm{AL} 85 \mathrm{~S} 83}$ & -0.49 & -0.46 & 0.17 & 1.09 & -0.52 & 1.32 & 0.31 & 0.46 & 0.47 & 0.60 \\
\hline 38 & $\Delta \mathrm{NNO}_{\mathrm{S} 08_{\mathrm{A}}}$ & 0.10 & 0.68 & 0.61 & 1.63 & 0.24 & 2.03 & 1.50 & 0.86 & 1.10 & 1.23 \\
\hline 39 & $\Delta \mathrm{NNO}_{\mathrm{G} 08 \_\mathrm{A}}$ & -0.48 & 0.11 & 0.04 & 0.92 & -0.32 & 1.20 & 0.82 & 0.27 & 0.48 & 0.60 \\
\hline 40 & $\Delta \mathrm{NNO}_{\mathrm{S} 08 \mathrm{~A} A \mathrm{AL} 85}$ & 0.20 & 0.23 & 0.74 & 1.62 & 0.18 & 1.86 & 0.86 & 1.00 & 1.01 & 1.13 \\
\hline 41 & $\Delta \mathrm{NNO}_{\mathrm{GE} 08 \mathrm{~A} A \mathrm{AL} 85}$ & -0.53 & -0.49 & 0.12 & 1.04 & -0.56 & 1.27 & 0.26 & 0.42 & 0.42 & 0.55 \\
\hline 42 & $\Delta \mathrm{NNO}_{\mathrm{S} 08 \text { в }}$ & 0.03 & 0.61 & 0.54 & 1.54 & 0.15 & 2.01 & 1.49 & 0.80 & 1.01 & 1.10 \\
\hline 43 & $\Delta \mathrm{NNO}_{\text {GEO8 B }}$ & -0.57 & -0.63 & -0.18 & 1.28 & -0.63 & 1.30 & 0.29 & 0.51 & 0.32 & 0.40 \\
\hline
\end{tabular}

and printed by the Grapher, available from the Golden software. These plots appear on the screen by selecting desired diagram type from the pull-down menu of Graph in the Calculation Screen window.

WinMIgob is a compiled program that consists of a self-extracting setup file including all the necessary support files (i.e., with the extension of ". dll" and ". ocx" files) for the 32-bit system. If the Microsoft ${ }^{\mathbb{B}}$
Visual Studio package is not installed on the computer, all these support files are used by the program for proper execution. During the setup procedure, the program and its associated files (i.e., support files, help file, data files with the extensions of ".mi", ".xls", ".xlsx" and plot files with the extension of ".grf") are installed into the personal computer's " $\mathrm{C}: \backslash$ Program Files $\backslash$ WinMIgob" folder with the Windows XP or later operating 
Tab. 3 Notes:

Mt1-Il1 to Mt6-I16 pairs from Ghiorso (2008); Mt7-I17 and Mt8-I18 from Blundy et al. (2008); Mt9-I19 and Mt10-Il10 from Jolles and Lange (2019); Magnetite-ilmenite geothermometers of $T_{\mathrm{P} 77 \text { C67 }}$ (row 1) from Powell and Powell (1977) using the Carmichael (1967) method, $T_{\mathrm{P} 77 \text { A68 }}$

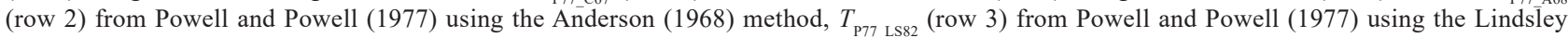
and Spencer (1982) method, $T_{\mathrm{P} 77 \mathrm{~S} 83}$ (row 4) from Powell and Powell (1977) using the Stormer (1983) method, $T_{\mathrm{SL} 81 \mathrm{C} 67}$ (row 5) from Spencer and Lindsley (1981) using the Carmichael (1967) method, $T_{\text {SL81 A68 }}$ (row 6) from Spencer and Lindsley (1981) using the Anderson (1968) method, $T_{\text {SL81_LS82 }}\left(\right.$ row 7) from Spencer and Lindsley (1981) using the Lindsley and Spencer (1982) method, $T_{\text {SL81_S83 }}$ (row 8) from Spencer and Lindsley (1981) using the Stormer (1983) method, $T_{\mathrm{AL} 85 \text { C67 }}$ (row 9) from Andersen and Lindsley (1985) using the Carmichael (1967) method, $T_{\mathrm{AL} 85}$ A68 (row 10) from Andersen and Lindsley (1985) using the Anderson (1968) method, $T_{\mathrm{AL} 85}$ Ls82 (row 11) from Andersen and Lindsley (1985) using the Lindsley and Spencer (1982) method, $T_{\mathrm{AL} 85 \mathrm{~S} 83}$ (row 12) from Andersen and Lindsley (1985) using the Stormer (1983) method, $T_{\mathrm{S} 08 \mathrm{~A}}$ (row 13) from Sauerzapf et al. (2008) calculated by WinMIgop, $T_{\mathrm{GE} 08 \mathrm{~A}}$ (row 14) from Ghiorso and Evans (2008) based on the linear regression equation [ $T_{\mathrm{GE} 08}$ $\left.\left({ }^{\circ} \mathrm{C}\right)=1.098258692 \times T_{\mathrm{s} 08}-67.18937519\right]$ between Sauerzapf et al. (2008) and Ghiorso and Evans (2008) calibrations calculated by WinMIgop, $T_{\text {S08 A AL85 }}$ (row 15) from Sauerzapf et al. (2008) by selecting Sauerzapf et al. (2008) thermometer through least-squares using model by Andersen and Lindsley (1985) option from the pull-down-menu of Geothermometer in the Start-up Screen window of program, $T_{\text {GE0 A AL85 }}$ (row 16) from Ghiorso and Evans (2008) by selecting Ghiorso and Evans (2008) thermometer through least-squares using model by Andersen and Lindsley (1985) option from the pull-down-menu of Geothermometer in the Start-up Screen window of program, $T_{\text {s08 }}$ ( estimation developed by Sauerzapf et al. (2008), $T_{\mathrm{GE} 08 \text { B }}$ (row 18) from Ghiorso and Evans (2008) calculated by online link [http://melts.ofm-research.org/CORBA_CTserver/OxideGeothrm/OxideGeothrm.php]; Magnetite-ilmenite oxygen barometers of $f \mathrm{O}_{2}$ pp77 c67 (row 19) from Powell and Powell (1977) using the Carmichael (1967) method, $f_{2} \mathrm{P}_{277}$ A68 (row 20) from Powell and Powell (1977) using the Anderson (1968) method, $\mathrm{fO}_{2 \text { Pp77 Ls82 }}$ (row 21) from Powell and Powell (1977) using the Lindsley and Spencer (1982) method, $f \mathrm{O}_{2}$ pp77 s83 (row 22 ) from Powell and Powell (1977) using the Stormer (1983) method, $f_{2} \mathrm{sL}_{\text {s1 C67 }}$ (row 23) from Spencer and Lindsley (1981) using the Carmichael (1967) method, $f \mathrm{O}_{2}$ sL81 $\mathrm{A}_{68}$ (row 24) from Spencer and Lindsley (1981) using the Anderson (1968) method, $f \mathrm{O}_{2}$ sL81 Ls82 (row 25) from Spencer and Lindsley (1981) using the Lindsley and Spencer (1982) method, $f_{2} \mathrm{O}_{2 \mathrm{sL} 81 \mathrm{~s} 83}$ (row 26) from Spencer and Lindsley (1981) using the Stormer (1983) method, $f \mathrm{O}_{2}$ al85 $\mathrm{C}_{67}$ (row 27) from Andersen and Lindsley (1985) using the Carmichael (1967) method, $\mathrm{fO}_{2} \mathrm{AL}_{85} \mathrm{~A} 68$ (row 28) from Andersen and Lindsley (1985) using the Anderson (1968) method, $\mathrm{fO}_{2} \mathrm{AL}_{5} \mathrm{Ls} 82$ (row 29) from Andersen and Lindsley (1985) using the Lindsley and Spencer (1982) method, $f \mathrm{O}_{2}$ aL85 $\mathrm{s}_{33}$ (row 30) from Andersen and Lindsley (1985) using the Stormer (1983) method, fO $\mathrm{O}_{2}$ sos A (row 31) from Sauerzapf et al. (2008) calculated by WinMIgop, $\mathrm{fO}_{2} \mathrm{~s}_{08 \mathrm{~A} \text { AL85 }}$ (row 32) from Sauerzapf et al. (2008) by selecting log fO2 (Sauerzapf et al., 2008) through least-squares using model by Andersen and Lindsley (1985) option from the pull-down-menu of Oxygen barometer in the Start-up Screen window of program, $\mathrm{O}_{2}$ s08 B (row 33) from Excel spreadsheet estimation developed by Sauerzapf et al. (2008); Log oxygen fugacity values relative to nickel-nickel oxide buffer of $\Delta \mathrm{NNO}_{\mathrm{AL} 85 \mathrm{C} 67}$ (row 34) from Andersen and Lindsley (1985) using the Carmichael (1967) method, $\Delta \mathrm{NNO}_{\mathrm{AL} 85 \mathrm{~A} 68}$ (row 35) from Andersen and Lindsley (1985) using the Anderson (1968) method, $\Delta \mathrm{NNO}_{\mathrm{AL} 85 \text { Ls82 }}$ (row 36) from Andersen and Lindsley (1985) using the Lindsley and Spencer (1982) method, $\triangle \mathrm{NNO}_{\mathrm{AL} 85 \mathrm{~S} 83}$ (row 37) from Andersen and Lindsley (1985) using the Stormer (1983) method, $\Delta \mathrm{NNO}_{\mathrm{S} 08 \mathrm{~A}}$ (row 38) from Sauerzapf et al. (2008) calculated by WinMIgop, $\Delta \mathrm{NNO}_{\mathrm{G}_{0} \mathrm{~A}_{\mathrm{A}}}$ (row 39) from Ghiorso and Evans (2008) based on the polynomial equation $\left[\Delta \mathrm{NNO}_{\mathrm{G} 08}=\right.$ $\left.-0.5806296664+1.083216766 \times \Delta \mathrm{NNO}_{\mathrm{s} 08}-0.1011931202 \times \Delta \mathrm{NNO}_{\mathrm{S} 08}{ }^{2}\right]$ between Sauerzapf et al. (2008) and Ghiorso and Evans (2008) calibrations calculated by WinMIgop, $\Delta \mathrm{NNO}_{\mathrm{S} 08 \mathrm{~A} \mathrm{AL}_{85}}$ (row 40) from Sauerzapf et al. (2008) by selecting DeltaNNO (Sauerzapf et al., 2008) through least-squares using model by Andersen and Lindsley (1985) option from the pull-down-menu of Oxygen barometer in the Start-up Screen window of program, $\triangle \mathrm{NNO}_{\mathrm{GE} 08 \mathrm{~A} \text { AL85 }}$ (row 41) from Ghiorso and Evans (2008) by selecting DeltaNNO (Ghioro and Evans, 2008) through least-squares using model by Andersen and Lindsley (1985) option from the pull-down-menu of Oxygen barometer in the Start-up Screen window of program, $\Delta \mathrm{NNO}_{\text {s08 }}$ (row 42) from Excel spreadsheet estimation developed by Sauerzapf et al. (2008), $\Delta \mathrm{NNO}_{\mathrm{GE} 08 \mathrm{~B}}$ (row 43) from Ghiorso and Evans (2008) calculated by online link [http://melts.ofm-research.org/CORBA_CTserver/OxideGeothrm/OxideGeothrm.php]

systems. However, an installation of the program into a personal computer with the 64-bit operating system may require the msflexgrd adjustment. This procedure is explained in detail in Electronic Supplementary Material (ESM 3) for the users. The self-extracting setup file is approximately $20 \mathrm{Mb}$ and may be downloaded from the journal server.

Acknowledgements. I am grateful for constructive reviews and comments from Eric Yang and Igor Petřík on an earlier draft, which improved the quality of the manuscript. I also thank handling editor, Igor Broska, and Jakub Plášil, Editor-in Chief, for their valuable contributions.

Electronic supplementary material. Examples of magnetite-ilmenite data recalculated and plotted by the WinMIgop program (ESM 1), comparison of $\mathrm{Fe}_{2} \mathrm{O}_{3}$ and $\mathrm{FeO}$ (wt. \%) input (e.g., wet-chemical) with $\mathrm{FeO}_{\text {tot }}$ (wt. \%) contents (e.g., electron-microprobe) in the estimation of temperature $\left({ }^{\circ} \mathrm{C}\right)$ and oxygen fugacity $\left(f \mathrm{O}_{2}\right)$ values (ESM 2), the steps for WinMIgop program execution (ESM 3) and self-extracting WinMIgop. exe setup file are available online at the Journal web site (http:// dx.doi.org/10.3190/jgeosci.319).

\section{References}

ANDERSEN DJ, LindSLey DH (1985) New (and final!) models for the $\mathrm{Ti}$-magnetite/ilmenite geothermometer and oxygen barometer. Abst AGU 1985 Spring Meeting Eos Transactions. AGU 66 (18), 416.

ANDERSEN DJ, LINDSLEY DH (1988) Internally consistent solution models for Fe-Mg-Mn-Ti oxides: Fe-Ti oxides. Amer Miner 73: 714-726

ANDERSON AT (1968) Oxidation of the LaBlache Lake titaniferous magnetite deposit, Quebec. J Geol 76: 528-547

ArATór, AudÉTAT A(2017) FeTiMM-A new oxybarometer for mafic to felsic magmas. Geochem Perspect Lett 5: 19-23 
BaCON CR, Hirschmann MM (1988) Mg/Mn partitioning as a test for equilibrium between Fe-Ti oxides: Amer Miner 73: 57-61

Blundy J, Cashman KV, Berlo K (2008) Evolving Magma Storage Conditions Beneath Mount St. Helens Inferred from Chemical Variations in Melt Inclusions from the 1980-1986 and Current (2004-2006) Eruptions. In: Sherrod DR, Scott WE, Stauffer PH (eds) A Volcano Rekindled: The Renewed Eruption of Mount St. Helens, 2004-2006. USGS Prof Pap 1750, pp 755-790

BUDDINGTON AF, LindSLEY DH (1964) Iron-titanium oxide minerals and synthetic equivalents. J Petrol 5: 310-357

CARMichael ISE (1967) The iron-titanium oxides of salic volcanic rocks and their associated ferromagnesian silicates. Contrib Mineral Petrol 14: 36-64

Droop GTR (1987) A general equation for estimating $\mathrm{Fe}^{3+}$ concentrations in ferromagnesian silicates and oxides from microprobe analyses using stoichiometric criteria. Mineral Mag 51: 431-435

Evans BW, SCaillet B (1997) The redox state of Pinatubo dacite and the ilmenite-hematite solvus. Amer Miner 82: 625-629

Evans BW, Scaillet B, Kuehner SM (2006) Experimental determination of coexisting iron-titanium oxides in the systems FeTiAlO, FeTiAlMgO, FeTiAlMnO, and FeTi$\mathrm{AlMgMnO}$ at 800 and $900^{\circ} \mathrm{C}, 1-4 \mathrm{kbar}$, and relatively high oxygen fugacity. Contrib Mineral Petrol 152: 149-167

GHIORso MS (2008) The magnetite-ilmenite database (04GhiorsoDataTable.xls). http://earth.geology.yale. edu/ ajs/SupplementaryData/2008/ (accessed 15.08.20)

Ghiorso MS, CARMichael ISE (1981) A Fortran IV computer program for evaluating temperatures and oxygen fugacities from the compositions of coexisting iron-titanium oxides. Comput Geosci 7: 123-129

GHiorso MS, Evans BW (2008) Thermodynamics of rhombohedral oxide solid solutions and a revision of the $\mathrm{Fe}-\mathrm{Ti}$ two-oxide geothermometer and oxygen-barometer. Amer J Sci 308: 957-1039

Ghiorso MS, SACK O (1991) Fe-Ti oxide geothermometry: thermodynamic formulation and the estimation of intensive variables in silicic magmas. Contrib Mineral Petrol 108: 485-510

HiMMELBERG GR, Ford AB (1977) Iron-titanium oxides of the Dufek intrusion, Antarctica. Amer Miner 62: 623-633

Holland T, Blundy J (1994) Nonideal interactions in calcic amphiboles and their bearing on amphibole-plagioclase thermometry. Contrib Mineral Petrol: 116, 433-447

Honjo N, Bonnichesen B, LeEman WP, Stormer JC Jr (1992) Mineralogy and geothermometry of high-temperature rhyolites from the central and western Snake River Plain. Bull Volcanol: 54, 220-237

Hora JM, Kronz A, Möller-Mcnett S, Wörner G (2013) An Excel-based tool for evaluating and visualizing geothermobarometry data. Comput Geosci 56: 178-185
Jolles JSR, LANGe RA (2019) High-resolution Fe-Ti oxide thermometry applied to single-clast pumices from the Bishop Tuff: a re-examination of compositional variations in phenocryst phases with temperature. Contrib Mineral Petrol: 174, 1-43

Lanari P, Vidal O, De Andre V, Dubacq B, Lewin E, Grosch EG, Schwartz S (2014) XMapTools: a MATLAB $^{\circ}$-based program for electron microprobe $\mathrm{X}$-ray image processing and geothermobarometry. Comput Geosci 62: 227-240

Lattard D, Sauerzapf U, Käsemann M (2005) New calibration data for the Fe-Ti oxide thermo-oxybarometers from experiments in the $\mathrm{Fe}-\mathrm{Ti}-\mathrm{O}$ system at $1 \mathrm{bar}$, $1,000-1,300{ }^{\circ} \mathrm{C}$ and a large range of oxygen fugacities. Contrib Mineral Petrol 149: 735-754

LEPAGE LD (2003) ILMAT: an Excel worksheet for ilmenite-magnetite geothermometry and geobarometry. Comput Geosci 29: 673-678

Li W, Cheng Y, Yang Z (2019) Geo- $f \mathrm{O}_{2}$ : Integrated software for analysis of magmatic oxygen fugacity. Geochem Geophys Geosyst 20: 2542-2555

LindSLEY DH, Frost BR (1992) Equilibria among Fe-Ti oxides, pyroxenes, olivine, and quartz: part I. Theory. Amer Miner 77: 987-1003

LiNDSLEY DH, SPENCER KJ (1982) Fe-Ti oxide geothermometry: Reducing analyses of coexisting Ti-magnetite (Mt) and ilmenite (llm). Trans Amer Geophys Un (EOS) 63: 471

MisRA KC (2012) Introduction to Geochemistry Principles and Applications. Wiley-Blackwell, UK, pp 1-438

Mullen EK, McCallum IS (2013) Coexisting pseudobrookite, ilmenite, and titanomagnetite in hornblende andesite of the Coleman Pinnacle flow, Mount Baker, Washington: Evidence for a highly oxidized arc magma. Amer Miner 98:417-425

ONDREJKA M, BROSKA I, UhER P (2015) The late magmatic to subsolidus $T-f \mathrm{O}_{2}$ evolution of the Lower Triassic Atype rhyolites (Silicic Superunit, Western Carpathians, Slovakia): Fe-Ti oxythermometry and petrological implications. Acta Geol Slov 7: 51-61

Powell R, Powell M (1977) Geothermometry and oxygen barometry using coexisting iron-titanium oxides: a reappraisal. Mineral Mag 41: 257-263

PUTIRKA K (2008) Thermometers and barometers for volcanic systems. In: PutiRKa KD, TePley III FJ (eds) Minerals, Inclusions And Volcanic Processes. Mineralogical Society of America and Geochemical Society Reviews in Mineralogy and Geochemistry 69, Washington, pp $61-120$

Rao DR, Choubey VM, Rao TV (1991) ITHERM: A Basic program for magnetite-ilmenite thermometry. Comput Geosci 17: 307-314

Sauerzapf U, Lattard D, Burchard M, Engelmann R (2008) The titanomagnetite-ilmenite equilibrium: New experimental data and thermo-oxybarometric applica- 
tion to the crystallization of basic to intermediate rocks. J Petrol 49: 1161-1185

Spencer KJ, Lindsley DH (1981) A solution model for coexisting iron-titanium oxides. Amer Miner 66: 1189-1201

STORMER JC Jr (1983) The effects of recalculation on estimates of temperature and oxygen fugacity from analyses of multicomponent-iron-titanium oxides. Amer Miner 68: 586-594

VeneZky DY, Rutherford MJ (1999) Petrology and Fe-Ti oxide reequilibration of the 1991 Mount Unzen mixed magma. J Volcanol Geotherm Res 89: 213-230

WANG R, Richards JP, Hou ZQ, YANG ZM, Gou ZB, DuFRANE SA (2014) Increasing Magmatic Oxidation State from Paleocene to Miocene in the Eastern Gangdese Belt, Tibet: Implication for Collision-Related Porphyry $\mathrm{Cu}-\mathrm{Mo} \pm \mathrm{Au}$ Mineralization. Econ Geol 109: 1943-1965 YAVUZ F (1998) BIOAPAG-PC: Program for an apatite and biotite geothermometer. Comput Geosci 24: 885-891

YAVUZ F (2013) WinPyrox: a Windows program for pyroxene calculation classification and thermobarometry. Amer Miner 98: 1338-1359

YAVUZ F, DÖNER Z (2017) WinAmptb: a Windows program for calcic amphibole thermobarometry. Period di Mineral 86: $135-167$

YAVUZ F, YILDIRIM DK (2020) WinGrt, a Windows program for garnet supergroup minerals. J Geosci 65: 71-95 